\title{
ON THE GENUS ASPLENIUM IN THE IBERIAN PENINSULA
}

\author{
A. SLEEP
}

\begin{abstract}
SUMMARY: The Asplenium species recorded from the Iberian peninsula comprise diploids and tetraploids, and of the latter, both auto- and allotetraploids occur. Evidence from the meiotic pairing behaviour of the chromosomes in synthetic hybrids is adduced to show how the mode of origin and interrelationships of such species can be elucidated, and specific reference is made to Asplenium foresiense, A. majoricum, A. petrarchae and A billotii. The suggested occurrence of autopolyploidy in Asplenium cuneifolium is also discussed. Evidence is presented which shows that in the British Isles and Corsica serpentine plants previously regarded as autotetraploid derivatives of A. cuneifolium are in fact allotetraploid and almost certainly just specialized serpentine forms of Asplenium adiantum-nigrum. It is suggested that such forms of A. adiantum-nigrum could occur also on serpentine rocks elsewhere in western Europe, for example, in Spain and France.
\end{abstract}

RESUMEN: Las especies del genero Asplenium, registradas en la Peninsula Ibérica, comprenden citotipos diploides y tetraploides, siendo estos últimos tanto autotetraploides como alotetraploides. Del apareamiento miótico de los cromosomas en los híbridos sintéticos se aducen pruebas para mostrar como se pueden dilucidar el modo de origen y las interrelaciones de tales especies, y se hace referencia específica a Asplenium foresiense, A. majoricum, A. petrarchae y A. billotii. También se discute la cuestión de la autopoliploidía de A. cuneifolium que habia sido sugerida previamente. Se ofrecen datos experimentales que muestran que en las Islas Británicas y en Córcega las plantas que crecen sobre serpentinas, anteriormente consideradas como un derivado autotetraploidal de A. cuneifolium, son en realidad alotetraploides y, casi con certeza, no son más que formas serpentinícolas especializadas de A. adiantum-nigrum. Se sugiere que tales formas de A. adiantum-nigrum pueden existir también sobre serpentinas en otras partes de Europa occidental, por ejf $n$ lo, en España o Francia.

\section{INTRODUCTION}

The Iberian Peninsula, with its mountainous topography combined with a long Atlantic seaboard and Mediterranean coasts to the east and south, provides a varied climate and an abundance of di- 


\section{A. SLEEP}

verse habitats for ferns, and the flora is accordingly rich.Within Asplenium, for example, no less than nineteen of the thirty-one taxa recorded from Europe occur in the Iberian peninsula and its adjacent islands. These are listed in Table $i$, iugether with four species belonging to the three associated genera Phyllitis, Ceterach and Pleurosorus.

\begin{tabular}{|c|c|c|}
\hline ASPLENIUM & HEMIONITIS L. & $2 x$ \\
\hline ASPLENIUM & MARINUM L. & $2 \times$ \\
\hline ASPLENIUM & VIRIDE Hudson & $2 x$ \\
\hline ASPLENIUM & TRICHOMANES L. subsp. TRICHOMANES & $2 x$ \\
\hline ASPLENIUM & TRICHOMANES L. subsp. QUADRIVALENS D.E. Meyer & $4 \times$ \\
\hline ASPLENIUM & $\begin{array}{l}\text { SEELOSII Leybold subsp. GLABRUM (Litard. \& Mai- } \\
\text { re) Rothm. }\end{array}$ & $2 \times$ \\
\hline *ASPLENIUM & ONOPTERIS L. & $2 \times$ \\
\hline *ASPLENIUM & CUNEIFOLIUM Viv. & $2 \times$ \\
\hline *ASPLENIUM & FONTANUM (L.) Bernh. & $2 \times$ \\
\hline *ASPLENIUM & OBOVATUM Viv. & $2 \times$ \\
\hline *ASPLENIUM & $\begin{array}{l}\text { PETRARCHAE (Guérin) DC. subsp. BIVALENS (D.E. } \\
\text { Meyer) Lovis \& Reichstein }\end{array}$ & $2 \times$ \\
\hline *ASPLENIUM & PETRARCHAE (Guérin) DC. subsp. PETRARCHAE & $4 \times$ \\
\hline *ASPLENIUM & FORESIENSE Le Grand & $4 \times$ \\
\hline *ASPLENIUM & MAJORICUM Litard. & $4 \times$ \\
\hline *ASPLENIUM & ADIANTUM-NIGRUM L. & $4 \times$ \\
\hline *ASPLENIUM & BALEARICUM Shivas & $4 \cdot x$ \\
\hline *ASPLENIUM & BILLOTII F.W. Schultz & $4 \times$ \\
\hline ASPLENIUM & SEPTENTRIONALE (L.) Hoffm. & \\
\hline ASPLENIUM & RUTA-MURARIA L. & $4 \times$ \\
\hline CETERACH O & OFFICINARUM DC. subsp. OFFICINARUM & $4 \times$ \\
\hline PLEUROSORU & US HISPANICUS (Cosson) C.V. Morton & $2 \times$ \\
\hline PHYLLITIS & SCOLOPENDRIUM (L.) Newman & $2 \times$ \\
\hline PHYLLITIS & SAGITTATA (DC.) Guinea \& Heywood & $2 \times$ \\
\hline
\end{tabular}

Table I.- Aspleniaceae occurring in the Iberian Peninsula. Nomenclature follows Flora Europaea,1. 1964. (*) Species discussed in this paper.

In Europe, the genus Asplenium is notable in respect of the large number of diploid species which are known (approximately half of the recorded taxa); it is also remarkable for its morphological diversity, all ten Spanish diploid species, for example, being quite distinct and readily separated from each other. These species are also cytologically separate, and show complete failure of chromosome pairing when one is crossed with another. Polyploidy occurs, but in European Asplenium does not extend beyond the tetraploid level. Some fifteen fertile tetraploid taxa are recorded from Europe, and of these, nine occur in Spain (see Table I). Tetraploids can arise in two ways: by autopolyploidy (derived by doubling of the chromosome complement of a single diploid species), or by allopolyploidy (derived by hybridization between two distinct diploid species, followed by chromosome doubling). Examples of these two tetraploid types exist in the Spanish Asplenium flora, and some will be considered in this 1.alk today. The genus Asplenium also has a great capacity for forming hybrids, both in nature and in the laboratory, a facility which ha proved very useful to cytogeneticists, who are able to deduce, by means of the analysis of the meiotic pairing behaviour of the chromosomes in experimentally-produced synthetic hybrids, various facts about the origins and interrelationships of given species under 
investigation. By means of such methods, the relationships between the European species of Asplenium have now been worked out in some detail, largely through the efforts of Professor Lovis, Professor Reichstein and myself.

Today I shall be presenting the experimental evidence from that part of my work which has special relevance to the Spanish Asplenium flora, and I propose to restrict my remarks to those particular species marked by an asterisk in Table $I$.

\section{THE SPECIES INVESTIGATED}

I wish to consider first six interrelated species: A. fontanum, A. obovatum, A. petrarchae, A. foresiense, A. majoricum and A. billotii, the nature and relationships of which were elucidated as a result of an intensive hybridization programme which I carried out at Leeds during the early 1960s. Let us take each of these species in turn:

1. A. fontanum (L.) Bernh. (Figure 2, G ). This is a diploid species, and it clearly displays 36 bivalent chromosomes at meiosis. It occurs on limestone rocks from Spain to the north of Switzerland. It is found in the mountains of eastern Spain, in the central and eastern Pyrenees, the Maritime Alps and along the whole length of the French Alps and the Jura. It is recorded from Majorca, specimens from the vicinity of Sóller having been collected as late as 1917. It has not been seen there recently, although a specimen collected by Orell and regarded as a hybrid by Orell and Schulze (Jaquotot \& Orell, 1968, also quoted by Bonafé, 1977) is most probably A. fontanum (Lovis \& Reichstein, 1969). Herbarium specimens have been seen from: Valencia, Cuenca, Teruel, Huesca and the Pyrénées espagnoles (Aragón) and catalanes.

2. A. obovatum Viv. (Figure 2, B) is another diploid species, but, in contrast to $A$. fontanum, is never found on limestone; it generally occurs on ancient siliceous rocks, such as granite, gneiss and schist, and it may sometimes be found on old walls. It is never far from the sea. It shows a relict distribution within the Mediterranean region, where it frequently occurs on islands. Herbarium specimens have been seen from southern France, Corsica, Sardinia, Italy, Greece and Turkey. There are numerous collections of this fern from the eastern Mediterranean, where it is locally common on the islands of the Cyclades group. Records from Spain exist in the literature, although I myself have seen no convincing herbarium specimens of it from the Iberian peninsula. Fernandes (1960) and Pinto da Silva (1951, 1959) both suggest that the records for Portugal are the result of confusion between A. obovatum and A. billotii; this seems highly probable in view of the generally Atlantic distribution of A. billotii. Similarly, it is likely that the records for northern and central Spain figured by Jalas \& Suominen (1972) also refer to A. billotii.

3. A.petrarchae (Guérin) DC. (Figure 4, G) exists as two cytotypes, diploid and tetraploid, and these have been separated as subspecies bivalens (D.E. Meyer) Lovis \& Reichstein (Meyer, 1964, Lovis \& Reichstein, 1969) and subspecies petrarchae respectively. Both cytotypes are similar in appearance, and they occur on limestone rock. Subspecies petrarchae is found also on walls. A. petrarchae sens. lat. has a disjunct Mediterranean distribution, shown well. by Giacomini (in Fiori, 1943) and by Jalas \& Suominen (1972). In Spain it occurs from 


\section{A. SLEEP}

the Pyrenees to the south coast. I believe I am correct in saying that the diploid taxon, subsp. bivalens, is known so far from only a single locality near Ronda.

4. A. foresiense Le Grand (Figure 2, E) is a tetraploid species, and it clearly shows 72 bivalent chromosomes at meiosis. It is found throughout the Massif Central of France, which constitutes its centre of distribution; it also occurs in the eastern Pyrenees. Outliers of the main distribution are found in southern Switzerland and in northwestern Italy (Liguria). Although indicated for Corsica and Sardinia by Jalas \& Suominen (1972), its presence there is unlikely. In the literature and in herbaria this species has been confused with $A$. fontanum, A. obovatum, and, most of all, with A. billotii, and some Spanish records may possibly refer to these other species. This is almost certainly the case regarding records from Galicia, which are likely to be A. billotii. A. foresiense is found on ancient igneous rocks, on granite in particular, and its overall distribution is undoubtedly largely influenced by the geological incidence of such deposits. A closely-related species, A. macedonicum, occurs on similar rocks in southern Yugoslavia.

5. A. majoricum Litard. (Figure 3, E) is also tetraploid, and, as far as we know, is endemic to the island of Majorca. It grows in crevices of limestone walls which border the olive terraces in the vicinity of Sóller. Sporadic reports of this fern from the Spanish mainland may refer to other species (Sleep, 1967, Lovis \& Reichstein, 1969). However, it could possibly occur in suitable habitats on the mainland, and it may yet be found there.

6. A. billotii F.W. Schultz (Figure 4, E) too is tetraploid. Superficially rather similar to A. obovatum, it can be easily distinguished by its angular pinnules which bear sharply pointed teeth. This species has a markedly Atlantic distribution (see Jalas \& Suominen, 1972), extending northwards as far as the west of the British. Isles. It is widespread in Spain, Portugal and western France, and it occurs also in the Channel Islands, Madeira, the Canary Islands and the Azores. Although penetrating parts of the western Mediterranean area such as Corsica and Sardinia, where it overlaps with A. obovatum, it is probably absent from the eastern Mediterranean.

Of the six species described above, four are tetraploid. The hybridization programme mentioned earlier has provided evidence concerning the modes of origin of all four tetraploid taxa, and we now know that A. foresiense and A. majoricum are allotetraploid and $\mathbf{A}$. petrarchae and A. billotii are autotetraploid. The evidence on which these statements are based is presented below:

\section{ASPLENIUM FORESIENSE}

A. foresiense shows similarities to both A. fontanum and A. obovatum in its general appearance, and could therefore be related to one or both of these diploids. Hybrids were accordingly synthesized between $A$. foresiense and $A$. fontanum, on the one hand, and between A. foresiense and A. obovatum on the other (Sleep, 1966). The morphology of the first hybrid is shown in Figure 2, F, and of the second in Figure 2, C. Both hybrids show irregular meioses; both are triploid and clearly display 36 paired and 36 single chromosomes (shown in Plate $\mathrm{I}, \mathrm{a}$ and $\mathrm{C}$, and in Figure 5, A and C). These results are equivocal: without further evidence the pairing may be interpre- 
ted either as occurring between the genome contributed by their respective diploid parents (i.e. A. fontanum or A. obovatum) and one of the genomes of A. foresiense, or alternatively, as autosyndetic pairing between the constituent genomes of $A$. foresiense. These two possibilities are shown diagrammatically in iigure 1 .

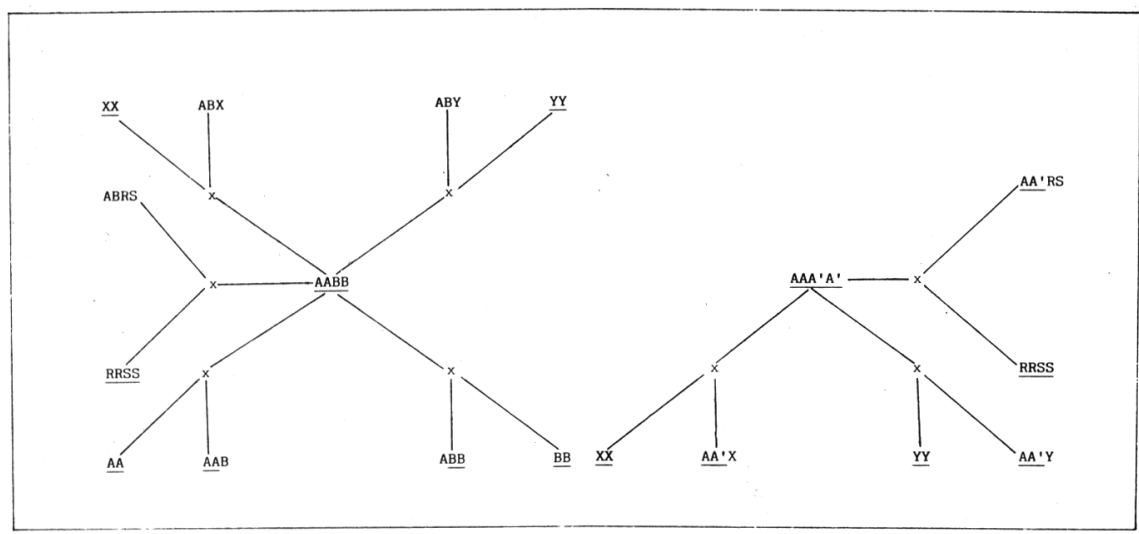

Figure 1.- Diagram to show the similarity of pairing behaviour shown by an allotetraploid, $A A B B$, crossed with its parent diploids ( $A A$ and $B B$ ) and an autotetraploid, AAA'A', crossed with two unrelated diploid species ( $X X$ and $Y Y$ ). Such equivocal results can be resolved by the production of 'wide' hybrids with unrelated species, also indicated on the diagram. Underlining bars indicate composition of bivalents formed in meiosis.

Fortunately evidence to distinguish between these alternatives is available in the form of another synthetic hybrid, this time between A. foresiense (Figure 2, E) and A. onopteris L. (Figure 2, D). This hybrid, shown in Figure 2, A, is triploid, and at meiosis 108 univalent chromosomes are clearly and regularly displayed (Sleep, 1966). This result (Plate I, b and Figure 5, B) shows (a) that the chromosomes of A. onopteris have no homology with either of the constituent genomes of $A$. foresiense, and (b) that the constituent genomes of A. foresiense have no homology with each other. A. foresiense must therefore be an allotetraploid. The pairing of 36 bivalents and 36 univalents consistently shown by triploid hybrids between different cultures of $\mathbf{A}$. foresiense and $\mathbf{A}$. fontanum thus demonstrates that $\mathbf{A}$. fontanum bears a part-parental relationship to A. foresiense. The parallel results observed in the hybrids between this tetraploid and $A$. obovatum show that these two species also share a common genome, and that A. obovatum must therefore be also an ancestor of A. fore- 
siense. A. foresiense has thus been shown to be an allotetraploid species which has arisen as a result of hybridization between the two diploid species, A. fontanum and A. obovatum, or forms with chromosomes homologous with these, followed by chromosome doubling.

\section{ASPLENIUM MAJORICUM}

Let us now consider Asplenium majoricum. This species, although described by de Litardière more than fifty years ago, remained a rather obscure taxon until interest in it was aroused as a result of the preparation of the account of Asplenium by Crabbe, Jermy \& Lovis for volume 1 of Flora Europaea (1964). Jermy \& Lovis (1964) were the first to examine the cytology of Asplenium majoricum, and they showed it to be a tetraploid species with 72 bivalent chromosomes visible at meiosis. A hybridization programme was set up at Leeds to determine the relationships of this species, and I was successful in producing hybrids in various combinations. The most important of these are listed in Table III.

The first hybrid, that between A. majoricum and A. fontanum (Figure 3, C), shows 36 paired and 36 unpaired chromosomes at meiosis (figured in sleep, 1967). As we have seen from the theoretical considerations outlined above (Figure 1), there are two possible interpretations of this pairing, namely:

1. that A. majoricum is an allotetraploid species and that the diploid A. fontanum is part-parental to it, or

2. that A. majoricum is an autopolyploid, the pairs observed being autosyndetic in origin.

The second possibility is in this case discounted by evidence available from two further hybrids, the first a triploid cross between A. majoricum and A. onopteris L. (Figure 3, I). This shows 108 univalent chromosomes at meiosis (Sleep, 1967). A hybrid was also synthesized between A. majoricum and A. viride Huds. (Figure 3, G). This is also triploid, and it similarly shows complete absence of any chromosome pairing (Sleep, 1967).

These two results demonstrate unequivocally the total lack of homology between the two constituent genomes of Asplenium majoricum, and it may thus be concluded that this species is an allotetraploid and that A. fontanum is one of its parents. What is the second parent? We may immediately exclude both $A$. onopteris and $A$. viride as possible ancestors on the evidence supplied by the two hybrids mentioned above. Further information from other synthetic hybrids (Sleep, 1966, 1967), including A. majoricum $\times$ A. foresiense (Figure 3, B) enables A. obovatum to be ruled out; A. trichomanes subsp. trichomanes can similarly be excluded on the basis of evidence sup-. plied by the synthesized hybrid A. majoricum $\times$ A. adulterinum (Lovis \& Reichstein, 1969). Professor Lovis, following up the suggestion of Professor Reichstein that the diploid form of Asplenium petrarchae (the subsp. bivalens) could be involved, synthesized the hybrid between this diploid and A. majoricum: it showed 36 paired and 36 unpaired chromosomes at meiosis (Lovis \& Reichstein, 1969), thus confirming that A. petrarchae subsp. bivalens is indeed the second parent of A. majoricum. 


\section{AUTOTETRAPLOIDS}

This conclusion leads us on to a consideration of our third tetraploid species, A. petrarchae. As we have seen, two cytotypes of similar morphology are known and it therefore seemed very likely that the tetraploid could be derived directly from the diploid by chromosome doubling. Evidence in confirmation of this view is provided by two more synthetic hybrids, A. petrarchae $x$ A. fontanum and A. billotii $\times$ A. petrarchae. A. petrarchae $x$ A. fontanum (Figure 4, H) is a triploid hybrid which shows 36 paired and 36 unpaired chromosomes at meiosis (Plate I, d and Figure 5, E), a result which, as we have already seen (Figure 1), can be interpreted in two different ways. Fortunately, we can confidently exclude one of the two possibilities by reference to plants of the hybrid combination A. billotii $\times$ A. petrarchae. These hybrid plants are quite obviously intermediate between the parents (Figure 4, F), but they show, not abortive spores, as would be expected, but a high proportion of good,well-filled spores. They are tetraploid, and at meiosis almost complete pairing of the chromosomes is regularly observed (Plate I, $h$ and Figure 5, F). The very high number of paired chromosomes excludes completely an allopolyploid origin for either A. petrarchae or A. billotii, apart from the most improbable suggestion that both these morphologically dissimilar species are alloploid on the same two parental diploids. The most likely conclusion is that both these very different tetraploids are autotetraploid in origin, and that the bivalents observed in hybrids between them are due to autosyndetic pairing within the constituent genomes of each species. An interesting parallel is the meiotic behaviour observed in both British and Italian examples of Asplenium $x$ murbeckii, the wild hybrid between $A$. septentrionale and $A$. rutamuraria subsp. ruta-muraria (Lovis, 1963, 1964). Other wild hybrids showing similar behaviour at meiosis are now also known (see, for example, Callé, Lovis \& Reichstein, 1975). A. petrarchae subsp. petrarchae is thus almost certainly an autotetraploid, and it can be expected to form up to 36 bivalents in any hybrid involving a species with which it is unrelated. That this is in fact the case is shown by the meiotic pairing behaviour of the hybrid A. petrarchae $x A$. fontanum, described above.

A positive relationship between the diploid and tetraploid cytotypes of A. petrarchae is demonstrated by the wild hybrid, Asplenium $x$ sollerense (Lovis, Sleep \& Reichstein, 1969). This is the hybrid between A. majoricum and A. petrarchae subsp. petrarchae. It is tetraploid, and it shows an irregular meiosis with 12 to 15 trivalent associations. Since we now know that A. majoricum is an allotetraploid species having the diploid A. petrarchae as one parent, we may conclude that in $A$. $x$ sollerense three genomes of $A$. petrarchae (one contributed by A. majoricum and two by A. petrarchae subsp. petrarchae) are all attempting to pair with one another. This hybrid thus provides strong evidence in favour of the view that A. petrarchae subsp. petrarchae has arisen by autopolyploidy from A. petrarchae subsp. bivalens.

That A. billotii too, is autotetraploid, is a conclusion which was formulated by Sleep (1966) on the basis of the pairing behaviour observed in the synthetic hybrids $A$. billotii $\times A$. petrarchae and $A$. majoricum $\times$ A. billotii. The latter hybrid is tetraploid, and at meiosis it clearly displays 36 bivalent and 72 univalent chromosomes (Plate $\mathrm{I}$, e and Figure 5, G). Had this result stood alone, there could have been two possible interpretations, namely (i) that A. billotii is an allotetraploid having one parent in common with A. majoricum, 
or (ii) that A. billotii is autotetraploid and that the 36 bivalents observed in the hybrid are formed by autosyndesis between the two chromosome sets contributed by the billotii parent. That the second interpretation is the correct one is shown by the pairing behaviour recorded in the two hybrids A. billotii $x$ A. petrarchae. The high degree of bivalent formation observed in these hybrids provided evidence to show that A. billotii, as well as A. petrarchae, was autotetraploid, a conclusion which has since been confirmed by the work of Lovis \& Vida (1969) on X Asplenophyllitis microdon ( = A . billotii $x$ Phyllitis scolopendrium). In both wild and synthetic examples of this cross 31-36 bivalents are consistently observed (Girard \& Lovis, 1968, Lovis \& Vida, 1969). A. billotii, like A. petrarchae, thus shows autosyndetic pairing in hybrids incorporațing species unrelated to it, and this behaviour has already been clearly demonstrated in the synthesized hybrid A. majoricum $x$ A. billotii which was mentioned above. It may be instructive, if at first sight confusing, to point out that the chromosome pairing behaviour in the hybrid A. majoricum $x$ A. billotii closely parallels that recorded from another synthetic tetraploid hybrid, namely A. majoricum $x$ A. foresiense (Figure 3, B); this also shows 36 bivalents and 72 single chromosomes (Sleep, 1966, 1967). In the latter case, however, the pairing is not autosyndetic in origin but comes from a totally different source. Here it arises from the combination of two fontanum genomes, one contributed by the A. majoricum parent and the other by the foresiense parent (see Figures 1 and 6).

We now come to the question of possible ancestral types. In the case of A. petrarchae, the diploid and tetraploid cytotypes are closely similar in morphology. In the case of A. billotii, there is a diploid candidate, namely A. obovatum. These two species can be distinguished morphologically, and indeed, are recognized taxonomically; they also possess somewhat different distributions. Evidence that the two are nevertheless intimately related is provided by yet another synthetic hybrid, namely A. billotii $x$ A. foresiense (Figure 4, D). This hybrid (Sleep, in preparation) behaves just like A. $x$ sollerense (A. majoricum $x$ A. petrarchae subsp. petrarchae), and a similar proportion of trivalent associations (of the order 12-15 per cell) is seen (Plate I,f and Figure 5,D). A. $x$ sollerense combined three petrarchae genomes; similarly the hybrid $A$. billotii $x$. foresiense combines three obovatum genomes, one from A. foresiense and two from A. billotii. We may thus conclude that, although they do look rather different. A. billotii has nevertheless arisen by chromosome doubling from A. obovatum or a form with chromosome homologous to it.

We may now combine the data from the above-mentioned hybrids (see Figure 6). Within this group of Asplenium, only two triploid hybrids are lacking, namely A. obovatum $x$ A. billotii and A. petrarchae subsp. bivalens $\times$ A. petrarchae subsp. petrarchae. A. obovatum $x$ A. billotii was synthesized by myself in 1966, and herbarium specimens are preserved, but unfortunately the plants died before cytological results could be obtained from them. I would expect both hybrids to show trivalent formation, as in $\mathrm{A}$. billotii $\mathrm{x} A$. foresiense and $\mathrm{A}$. $x$ sollerense.

An initially small hybridization programme, established to investigate the relationships of a Spanish endemic species of uncertain affinity, has thus led to the elucidation of the complex interrelationships of six European Asplenium species. We have seen that the diploid species, A. fontanum, has participated in the origin of two allotetraploids, A. foresiense and A. majoricum, whilst A. obovatum and 
A. petrarchae subsp. bivalens, as well as making their respective contributions to the formation of these two tetraploids, have each given rise to an autotetraploid species. The tetraploid A. petrarchae closely resembles its diploid progenitor, whilst A. billotii has, in its gross morphology, diverged considerably from A. obovatum.

\section{THE QUESTION OF AUTOPOLYPLOIDY IN ASPLENIUM CUNEIFOLIUM}

The mixture of auto- and allopolyploids which has been described above with reference to Spanish material reflects the situation in European Asplenium in general, where both sorts of tetraploid are also known. In addition to $A$. petrarchae and A. billotii, there is well-documented evidence for three other autotetraploid species: A. septentrionale, A. ruta-muraria subsp. ruta-muraria and A. trichomanes subsp. quadrivalens (Lovis, 1963, 1964, 1977). Autotetraploids exist also in the related genera Phyllitis (Emmott, 1964) and Ceterach (Vida, 1963, 1966). Therefore the suggestion of Deschatres, Schneller \& Reichstein (1978) that an autotetraploid form of Asplenium cuneifolium might exist in Corsica was not inherently improbable. That it is not correct, however, has now been established as a result of evidence provided by the following hybridization programme. Plants resembling A. cuneifolium Viv. (a European diploid species characteristically associated with serpentine rocks and illustrated in Figure 7 , C) had been collected from serpentine rocks in Corsica in 1974 and progeny from them were found to be tetraploid (Deschatres, Schneller \& Reichstein, 1978). At about the same time, plants collected from various serpentine localities in Scotland and identified as A. cuneifolium Viv. by Roberts \& Sirling (1974), were shown to be, not diploid, as had been thought, but tetraploid (Sleep et al., 1978); these corresponded so well with the material from Corsica that it was thought possible that they, too, could be autotetraploid. In order to test this hypothesis, a hybridization programme was set up at Leeds in the summer of 1978. As we have already seen (Figure 1) an autotetraploid species will produce a constant degree of bivalent formation in any hybrid involving another species which is unrelated to it. An allotetraploid, on the other hand, will show complete failure of chromosome pairing in a hybrid with an unrelated species. Attempts were therefore made to synthesize "wide" hybrids, i.e. hybrids between the tetraploid under investigation, in this case the so-called autotetraploid A. cuneifolium, and either an unrelated diploid (such as a species of Phyllitis) or an unrelated allotetraploid species of known parentage. Crosses were made using a number of different species, and hybrids were successfully synthesized with two unrelated allotetraploid species which are in themselves rather spectacular. The first is Asplenium kobayashii Tagawa (Figure 7, A), a rare Japanese allotetraploid which is derived from a cross between Camptosorus sibiricus Rupr. and Asplenium incisum Thunb. (Lovis \& Sleep, in preparation). The second is Phyllitis hybrida (Milde) C. Chr. (Figure 7, B), another very rare allotetraploid, this time derived from a cross between the diploid Ceterach (described as Asplenium javorkeanum Vida) and Phyllitis sagittata (DC.) Guinea\&Heywood (Vida, 1963). Both of these, because of their spectacular inter-generic origins, show no homology between their constituent genomes and are therefore valuable standards to use in an investigation of this sort. Hybrids have been made between the putative autotetraploid A. cuneifolium from Banff, Scotland, and A. kobayashii, and between putative autotetraploid A. cuneifolium from Lime Hill (another Scottish serpentine locality) and Phyllitis hybrida. The latter hybrid. is of particular interest, since it combines the chromosome sets of three so-called genera:Asplenium, Phyllitis and 
Ceterach. The chromosomes of the Phyllitis genome are much bigger than those of the other two genomes, and can be readily distinguished (Plate I, i). Both hybrids show virtually complete failure of chromosome pairing (Plate $I, k$ and $i$ ), with either all, or almost all, the chromosomes appearing as univalents. Although an occasional bivalent can sometimes be observed as in Plate I, i, this is insufficient to invalidate the conclusion that there is no effective homology between any of the four genomes combined in each hybrid. It therefore follows that in both cases the culture of putative autotetraploid $\mathbf{A}$. cuneifolium is not autopolyploid, as had been suspected, but allopolyploid. These results thus demonstrate quite clearly that two different Scottish serpentine populations of putative autotetraploid A. cuneifolium are in fact allotetraploid. Material of the putative autotetraploid A. cuneifolium from Corsica was also included in the hybridization programme, and hybrids with A. kobayashii were successfully raised. I have only very recently obtained cytological evidence from one of these hybrids, and it has not been possible to include in this paper a photograph of meiosis. Despite this, the evidence is quite clear. Complete failure of chromosome pairing was observed, thus demonstrating that the Corsican material is not, as had been suggested, autotetraploid but, like the plants from the Scottish serpentines, is allotetraploid.

Can we identify this allotetraploid? I am in no doubt that the Scottish and Corsican plants under discussion are all serpentine forms of Asplenium adiantum-nigrum L. This is a fern (Figure 8, B) which is probably familiar to you all, as it is found throughout Europe, in habitats both natural and man-made, occurring on rock and on walls and in hedgebanks. It is a vigorous allotetraploid species (Lovis \& Vida, 1969) which also shows complete failure of chromosome pairing when crossed with A. kobayashii (Plate I, l). A. adiantumnigrum has been shown by Shivas $(1956,1969)$ to derive from a cross between the diploid species A. onopteris L. (Figure 2, D) and A. cuneifolium Viv. (Figure 7, C). In order to test the hypothesis that tetraploid plants previously attributed to A. cuneifolium are in fact specialized serpentine forms of A. adiantum-nigrum, crosses were made between the Scottish serpentine material from Banff (which had already been incorporated into hybrids with A. kobayashiil and the "typical" form of A. adiantum-nigrum from Guernsey (Sleep, 1980). If the two are in fact the same, the hybrid between them can be expected to show complete pairing of the chromosomes at meiosis. Hybrids proved very easy to obtain, and 104 were produced from the same number of inseminations (see Table V). In this type of cross, it can be very difficult to determine if the plants raised from a hybridization attempt are in fact hybrids, or just selfed progeny arising from self-fertilization of the female parent. In this case, the parental stocks were of distinctive morphology, and hybrids between them could be recognized by their intermediate appearance as well as by hybrid vigour. Cells from the hybrid plants so far analysed have consistently shown either complete or virtually complete pairing of the chromosomes at meiosis (Plate I, g), a result which accords with the hypothesis that the Scottish serpentine material under investigation is neither A. cuneifolium nor an autotetraploid derivative of that species, but a form of A. adiantum-nigrum.

To date, tetraploid plants, originally identified either as A. cuneifolium or an autotetraploid cytotype of that species, have been collected from serpentine rocks in Corsica and from similar rocks in certain widely dispersed localities throughout the British Isles: these include Cornwall (Sleep, in preparation), seven separate sites in Scotland and one in the west of Ireland (Sleep et al., 1978). The cytoge- 
netic evidence already described clearly demonstrates an allopolyploid origin for some of this material (Corsica, Cornwall and two of the Scottish sites); evidence has also been presented which demonstrates that the one of these populations so far investigated (Banff) is without doubt a form of Asplenium adiantum-nigrum. In view of this mounting body of evidence, it seems to me highly probable that all the tetraploid material which has been collected from the serpentine habitats mentioned above will prove to be, like the population from Banff, a specialized ecological variant of A. adiantum-nigrum. The diploid species, A. cuneifolium Viv., is already known to occur on serpentine rocks. The existence on such ultra-basic rocks of specialized forms of A. adiantum-nigrum which appear to overlap with A. cuneifolium in their morphological characteristics is a rather surprising discovery. We cannot at this stage know whether the British and Corsican plants so far found are isolated examples of this phenomenon, or whether such serpentine forms of A. adiantum-nigrum are of widespread occurrence within Europe. Their existence, however, immediately poses furtiner questions, for example,

(i) can serpentine forms of $A$. adiantum-nigrum be distinguished on gross morphological characters from plants of the diploid species A. cuneifolium Viv.?

(ii) if so, is this morphological distinction accompanied by a corresponding distributional pattern?

In an attempt to answer these questions cytologically-determined material of A. cuneifolium and of serpentine forms of A. adiantum-nigrum was first examined; a study was then made of all the specimens in the collections of the National Herbaria at Kew and the British Museum (Natural History) which have been attributed to A. cuneifolium. My observations are presented in two parts, namely (i) morphology, and (ii) distribution.

(i) Morphology: The plants of A. adiantum-nigrum from Scotland and Corsica mentioned above have certainly been thought by some authors to show a close similarity to A. cuneifolium Viv. I have made a detailed morphological comparison between cytologically attested specimens of A. adiantum-nigrum from serpentine localities in Scotland (known to be tetraploid) and cytologically attested diploid specimens of A. cuneifolium from Austria. My judgement is that, although there are resemblances between these two groups of plants, these are slight, whereas the differences appear to me to be more significant. A. cuneifolium is a delicate species, finely cut and with a loose, open frond which is either narrowly or broadly triangular. It is almost always tripinnate. The pinnae and pinnules are distinctly stalked. The shape of the pinnules is variable: they can be long and narrow, but arefrequently rhomboid and reminiscent of the segments in Asplenium ruta-muraria. Although the margins of the pinnules are certainly concave at the base, the stated occurrence of flabellate pinnules (Flora Europaea, 1) is, in my opinion, so occasional as to be useless as a distinguishing feature. The margins and tips of the pinnules are fringed with many tiny teeth, so as to be almost fimbriate, and the veins extend into the very tips of the teeth. In A. adiantum-nigrum the teeth are much coarser, and the veins generally stop short of the teeth. Another characteristic feature of this cytologically determined material of $\mathbf{A}$. cuneifolium is the appearance 
of the frond and pinna tips, which bear curious, irregular, fringed segments or "tassels" not seen in any other European Asplenium. On the other hand, the Scottish serpentine material now known to be A. adiantum-nigrum lacks many of these characters. It too has a broadly triangular, open, rather delicate frond, but it is bipinnate rather than tripinnate. The pinnule shape is very variable and therefore not helpful as a diagnostic character; the pinnules can be rounded, rhomboid, sometimes flabellate, and even occasionally narrow. These ferns also lack the fine teeth and curious frond and pinna tips which are characteristic of A. cuneifolium. The ends of the pinnae are more regular, and terminate in an obtusely rounded, toothed tip as in typical forms of $\mathbf{A}$. adiantum-nigrum. I also included. in this study specimens of the Corsican tetraploid; these, in my opinion, match the material from the Scottish serpentines more closely than they match the cytologically attested diploid specimens of A. cuneifolium. Having drawn up a list of diagnostic characters by which to separate A. cuneifolium and the serpentine forms of A. adiantum-nigrum, I examined all specimens referred to A. cuneifolium in the National Herbaria. Material of $A$. cuneifolium from private collections was also studied. In the event, it proved possible to divide the herbarium material into two unequal groups, A and B. Group A, which was by far the larger, corresponded in morphological characteristics to my cytologically attested diploid material of A. cuneifolium Viv. A much smaller group, B, comprising isolated specimens from serpentine rocks in the British Isles, Norway, France and Spain, which were closely similar to each other in appearance, matched very well with the cytologically attested allotetraploid material from Scotland and Corsica.

(ii) Distribution: Notes were then made concerning the distribution of the material studied. Group A, resembling the diploid material of A. cuneifolium, was largely confined to central and eastern Europe. Specimens were seen from Albania, Austria, Czechoslovakia, Hungary, Poland, Rumania and Yugoslavia. Outside this area, specimens which can with confidence be attributed to A. cuneifolium Viv. are rare; in Germany, for example, it grows only in the east, in Bavaria and Saxony. It is rare in Switzerland, and the only convincing material I have seen from Italy, besides the photograph of the Type material of Viviani, is from Piedmont. Material of group B, which had been separated off by virtue of its morphological similarity to the Scottish allotetraploids, was not of central or eastern European distribution, but came from western Europe, i.e. the British Isles, France, Spain and possibly Norway.

This survey of the herbarium material classified under A. cuneifolium shows that two distinct groups emerge both morphologically and distributionally. The first group, A, corresponds to the cytologically determined diploid material of A. cuneifolium in its morphological characteristics; we may therefore confidently identify this material as A. cuneifolium Viv. In addition, my conclusions concerning the distribution of A. cuneifolium (i. e. central and eastern Europe) are confirmed by independent cytological records (given 
in Löve, Löve \& Pichi-Sermolli, 1977), which show that plants from these areas attributed to A. cuneifolium have been proved to be diploid. Amongst the herbarium material investigated, some specimens (Group B) were found which corresponded closely in morphology to my cytologically attested tetraploid plants from Scottish serpentine localities; these can be distinguished on morphological grounds from the specimens of Group A. I believe these to be, not A. cuneifolium, but serpentine forms of A. adiantum-nigrum, such as have already been found in Scotland, Cornwall and Corsica. Apart from additional British material, isolated collections from France, Spain and Norway fell into this group (B), which thus tends to show a distribution patterns on present evidence limited to the west of Europe. At the time of delivery of this lecture, no independent cytological data were available for European material referable on morphological grounds to serpentine forms of A. adiantum-nigrum. However, a result from Spanish material has just become available and is clearly relevant to this discussion. Specimes collected at an altitude of $1,060 \mathrm{~m}$ from serpentine rocks between Ronda and $\mathrm{Sn}$. Pedro de Alcántara in the Sierra Bermeja (Province of Málaga) by Holttum, Rasbach, Reichstein and Sleep (16.X.1980), whish in morphology matched very closely the allotetraploid material from the Scottish serpentines, have now been examined cytologically and are unequivocally tetraploid. They are not therefore A. cuneifolium Viv., but are likely to be specialized serpentine forms of A. adiantum-nigrum. It seems possible that such for A. adiantum-nigrum may occur elsewhere on serpentine rocks in the Iberian Peninsula but that their identity has not been previously recognized because of confusion with A. cuneifolium. The cuestion of the occurrence of A. cuneifolium in the Iberian Peninsula iscontroversial. Flora Europaea indicated only a doubtful record from Spain although Galiano, Montserrat \& Valdés in Jalas \& Suominen (1972) record it from Galicia and from several localities in The Basque Provinces; the latter specimens, which are preserved in Madrid, have however, been shown be Rivas-Martínez, Izco \& Costa (1973) to be A. onopteris. Amaral Franco \& Rocha Afonso (1971) do not record A. cuneifolium from Portugal, although Pinto da Silva (1970) and Rivas-Martínez et al. (op. cit.) both assert that it grows there. Rivas-Martinez et al., in the same article, also record A. cuneifolium from serpentine areas of the Sierra Bermeja at an altitude of $1,060 \mathrm{~m}$. Without at least seeing herbarium material of their collections, it is impossible to say whether their Sierra Bermeja plants are A. cuneifolium or the serpentine form of A. adiantumnigrum, although indirect evidence suggesting that A. cuneifolium may also exist in places in the Sierra. Bermeja (perhaps at higher altitudes) is available in the forms of a triploid hybrid collected be professor Reichstein in the same area. The question must, for the time being, remain open. A detailed study needs to be made of herbarium material from both Spain and Portugal which has been identified as A. cuneifolium. In addition, living material from serpentine habitats throughout the Iberian Peninsula should be investigated cytologically.

What has so far become clear as a result of the preliminary work described here is the existence of two different but closely related Aspleniums of similar appearance on serpentine rocks in Europe. Cytological evidence has shown that British and Corsican plants, previously regarded as autotetraploid forms of A. cuneifolium Viv., are 


\section{A. SLEEP}

not of that origin but allotetraploid. Furthermore, Scottish material of this allotetraploid has been unequivocallyidentified as a serpentine form of A. adiantum-nigrum. Finally, the tetraploid counts recorded in material from serpentine rocks in the area of the Sierra Bermeja strongly suggest that identical serpentine forms of A. adiantum-nigrum occur in Spain also. It is my belief that such specialized ecological forms of A. adiantum-nigrum may occur quite widely on serpentine rocks throughout western Europe, but are as yet undetected: they could well be found in other localities in Spain, and in France and Norway, and perhaps elsewhere.

\section{CONCLUDING REMARKS}

Today I have shown something of the differing evolutionary mechanisms evidenced in certain Spanish Aspleniums. The empirical basis of this evidence has been the use of synthetic hybrids raised experimentally in laboratory conditions. Many hybrids within this genus are, however, likely to occur naturally in Spain. Perhaps it will be appropriate to close by mentioning some of the more spectacular hybrid combinations which are likely to be found wild in the Iberian peninsula. X Asplenophyllitis microdon (Figure 8, D), the hybrid between Asplenium billotii (Figure 8, E) and Phyllitis scolopendrium, could well occur in the western areas of the peninsula, and the much rarer X Asplenophyllitis jacksonii (the hybrid of A. adiantum-nigrum with P. scolopendrium) should also be sought. A hybrid with which I am personally familiar is A. $x$ sarniense (Figure $8, C$ ); this has the parentage A. billotii $x$ A. adiantum-nigrum (Figure 8 , B). It too could be found in such areas. It occurs in Guernsey (Sleep, 1971, Sleep \& Ryan, 1972) and northwestern France, and possibly Corsica (Badré \& Deschatres, 1979). Within European Asplenium at least forty hybrid combinations have been described and, as the fern flora of the Iberian peninsula becomes better known, many of these hybrids are likely to be discovered in Spain. In Majorca two wild hybrids involving A. majoricum have already been recorded: A. x orellii (Lovis \& Reichstein, 1969), the hybrid with A. trichomanes subsp. quadrivalens, and A. x sollerense (Lovis, Sleep \& Reichstein, 1969), the hybrid with A. petrarchae subsp. petrarchae. Finally, not a hybrid, but a species to be assiduously searched for in Spain, particularly in the southern parts, is the plant described as A. balearicum by Shivas in 1969 (Figure 8, A). This is a little-known fern having the parentage A. onopteris x A. obovatum (Shivas, 1969); although at present thought to be endemic to the island of Majorca, it could possibly occur elsewhere in the Mediterranean region. The history of its discovery and identification is as follows: material of an Asplenium was collected by Miss E. O'Nions in Majorca (unfortunately from an unspecified locality) and used by M.G. Shivas in her investigation of the Asplenium adiantum-nigrum complex in 1956. At that time the material was ascribed to the species A. obovatum Viv. ( $=A$. lanceolatum Huds.). Shivas (1956) suggested it was an allotetraploid species having A. onopteris as one parent. The cytological work of Manton \& Reichstein (1962) then showed that material previously classified as A. obovatum Viv. (= A. lanceolatum Huds.) comprised two cytotypes; they recommended the restriction of the name A. obovatum Viv. to the diploid and the use of the name A. billotii F.W. Schultz for the tetraploid. Such tetraploid specimens of the A. obovatum complex now distinguished as A. billotii were thought initially to be allotetraploid (Manton, 1961, Manton \& Reichstein, 1962) on the analogy of Shivas' 
suggestion about the Majorcan material investigated by her. However, the production by Sleep in 1966 of two synthetic hybrids involving A. billotii, namely A. billotii $X$ A. petrarchae and A. majoricum $X$ A. billotii (described above,page 17\&18), suggested strongly that $\mathrm{A}$. billotii was in fact autotetraploid. These conflicting results initiated a morphological re-examination of the plants used in the experimental hybridization programmes of Shivas (1956) and Sleep (1966); it was realized that the Majorcan plants studied by Shivas were not A. billotii at all, but a species new to science and described by her as A. balearicum in 1969. Final proof of the allotetraploid nature of this species was provided by Lovis, Brownsey, Sleep \& Shivas (1972). A. balearicum is still known only from the Type collection from Majorca. Presumably this fern exists elsewhere and may, for example, occur in mainland Spain. It is perhaps just one particularly interesting and elusive plant on which the members of the proposed Spanish Pteridological Society could focus their attention.

\section{ACKNOWLEDGEMENTS}

Some of the work described here was carried out as part of the requirement for the degree of Ph.D. of the University of Leeds. I am most grateful to Emeritus Professor I. Manton, F.R.S. for supervising the early part of this research and for her subsequent help and encouragement. I am indebted to members of the technical staff of the University of Leeds for their assistance, in particular to Mr. F.K. Horwood and Mr. P. Lee, formerly of the Plant Sciences Department, for the skill and resourcefulness which they applied to the cultivation of my research material, and to Mr. W.D. Brain and Mr. L. Child, of the Department of Biophysics, for their help with photography. Dr. Janet Souter assisted with the latter part of the investigation, and I am indebted to her for making some of the cytological preparations illustrated here. I am particularly grateful to Professor T. Reichstein, for supplying much of the experimental material and for his interest and support over many years. Thanks are also due to Mr. A. McG. Stirling for the loan of herbarium specimens.

I wish to make acknowledgement to the authorities of various herbaria, notably the British Museum (Natural History) and Kew, for allowing me access to their collections and for providing study facilities. Thanks are also due to the members of the staffs of these institutions who have helped me in my work.

Part of this research was carried out during the tenure of a Research Studentship from the Department of Scientific and Industrial Research (now the Science Research Council) from 1961 to 1964; I have also received financial support from the Leverhulme Trust, the University of Leeds Research Fund and the Linnean Society of London (Bonhote Trust), to all of whom I proffer my thanks.

\section{REFERENCES}

AMARAL FRANCO, J. - 1971 - Nova Flora de Portugal, 1 (Pteridophyta with the collaboration of M.L. ROCHA AFONSO). Lisbon.

BADRE, F. \& DESCHATRES, R. - 1979 - Les Ptéridophytes de la France, liste commentée des espèces (taxonomie, cytologie, écologie et répartitión générale). Candollea, 34: 379-457.

BONAFE BARCELO, F. - 1977.- Flora de Mallorca, 1. Mallorca: Editorial Moll. 
CALLE, J., LOVIS, J.D. \& REICHSTEIN, T. - 1975 - Asplenium x contrei (A. adiantum-nigrum $\mathrm{x}$ A. septentrionale) hybr. nova et la vraie ascendance de l'Asplenium x souchei Litard. Candollea, 30: 189-201.

CRABBE, J.A., JERMY, A.C. \& LOVIS, J.D. - 1964 - Account of the genus Asplenium in Flora Europaea, 1 (ed. T.G. Tutin et al.). Cambridge University Press.

DESCHATRES, R., SCHNELLER, J.J. \& REICHSTEIN, T. - 1978 - A tetraploid cytotype of Asplenium cuneifolium Viv. in Corsica. Br. Fern Gaz., 11 (6) : 343-344.

EMMOTT, J.I. - 1964 - A cytogenetic investigation in a Phyllitis-Asplenium complex. New Phytol., 63: 306-318.

FERNANDES, R. - 1960 - Notas sobra a Flora de Portugal VIII. Bol. Soc. broteriana s.2, 34: 99-165.

FIORI, A. - 1943 - Flora Italica Cryptogama, 5. Firenze.

GIRARD, P.J. \& LOVIS, J.D. - 1968 - The rediscovery of X Asplenophyllitis microdon, with a report on its cytogenetics. Br. Fern Gaz., 10 (1): $1-8$.

JALAS, J. \& SUOMINEN, J. (eds.) - 1972 - Atlas Florae Europaeae, 1. Helsinki.

JAQUOTOT, Ma. C. \& ORELL CASASNOVAS, J. - 1968 - Asplenium majoricum R. Litardière; su área de expansión en la sierra norte de Mallorca. Collectanea Bot. Barcinone, VII (1), $n \cong 29:$ 559-571.

JERMY, A.C. \& LOVIS, J.D. - 1964 - Asplenium majoricum Litardière. Br. Fern Gaz., 9 (5): 163-167.

LOVE, A., LOVE, D. \& PICHI-SERMOLLI, R.E.G. - 1977 - Cytotaxonomic Atlas of the Pteridophyta. Vaduz.

LOVIS, J.D. - 1963 - Meiosis in Asplenium x murbeckii from Borrowdale. Br. Fern Gaz., 9 (4): 110-113.

LOVIS, J.D. - 1964 - Autopolyploidy in Asplenium. Nature , Lond., 203, no: 4942: 324-325.

LOVIS, J.D. - 1977 - Evolutionary patterns and processes in ferns. In R, D. PRESTON \& H.W. WOOLHOUSE (eds.), Advances in Botanical Research, 4: 229-415. London: Academic Press.

LOVIS, J. D. \& REICHSTEIN, T. - 1969 - Der Farnbastard Asplenium x orellii hybr. nov. = Asplenium majoricum Litard. $x$ A. trichomanes L. subsp. quadrivalens D.E. Meyer und die Abstammung von A. majoricum. Ber. schweiz. bot. Ges., 79: 335-345.

LOVIS, J.D. \& VIDA, G. - 1969 - The resynthesis and cytogenetic investigation of $\mathrm{X}$ Asplenophyllitis microdon and X A. jacksonii. Br. Fern Gaz., 10 (2): 53-67.

LOVIS, J.D., SLEEP, A. \& REICHSTEIN, T. - 1969 - Der Farnbastard Asplenium $\mathrm{x}$ sollerense hybr. nov.= Asplenium majoricum Litard. $\mathrm{x}$ A. petrarchae (Guérin) DC. subsp. petrarchae. Ber. schweiz. bot. Ges., 79: 369376.

LOVIS, J.D., BROWNSEY, P.J., SLEEP, A. \& SHIVAS, M.G. - 1972 - The origin of Asplenium balearicum. Br. Fern Gaz., 10 (5): 263-268.

MANTON, I. - 1950 - Problems of cytology and evolution in the Pteridophyta. Cambridge University Press.

MANTON, I. - 1961 - Evolution in the Pteridophyta. In P..J Wanstall (ed.), A Darwin Centenary. B.S.B.I. Conf. Rep., 6: 105-119. London. 
MANTON, I. \& REICHSTEIN, T. - 1962 - Diploides Asplenium obovatum Viv. Bauhinia, 2 (1): 79-91.

MEYER, D.E. - 1964 - Uber neue und seltene Asplenien Europas. III. Ber. dt. bot. Ges., 77: 3-13.

PINTO DA SILVA, A.R. \& SOBRINHO, G.L. - 1950 - Flora vascular da serra do Gerês. Agronomia lusit., 12: 233-402.

PINTO DA SILVA, A.R. - 1959 - Plantas novas e novas areas para a flora de Portugal V. Agronomia lusit., 20: 217-247.

PINTO DA SILVA, A.R. - 1970 - A flora e vegetaçào das areas ultrabásicas do Nordeste Transmontano. Agronomia lusit., 30: 175-364.

RIVAS-MARTINEZ, S., IZCO, J. \& COSTA, M. - 1973 - Asplenium cuneifolium Viv. (A. serpentini Tausch) en Sierra Bermeja (Málaga). Trab. Dep. Bot. y F. Veg., 6: 23-30.

ROBERTS, R.H. \& STIRLING, A. McG. - 1974 - Asplenium cuneifolium Viv. in Scotland. Br. Fern.Gaz., 11 (1): 7-14.

SHIVAS, M.G. - 1956 - Some problems in cytology and taxonomy in the genera Polypodium and Asplenium. Unpublished Ph.D thesis, University of Leeds.

SHIVAS, M.G. - 1969 - A cytotaxonomic study of the Asplenium adiantum-nigrum complex. Br. Fern Gaz., 10 (2): 68-80.

SLEEP, A. - 1966 - Some cytotaxonomic problems in the fern genera Asplenium and Polystichum. Unpublished Ph.D. thesis, University of Leeds.

SLEEP, A. - 1967 - A contribution to the cytotaxonomy of Asplenium majoricum. Br. Fern Gaz., 9(8): 321-329.

SLEEP, A. - 1971 - A new hybrid fern from the Channel Islands. Br. Fern Gaz., 10 (4): 209-211.

SLEEP, A: - 1980 - On the reported occurrence of Asplenium cuneifolium and $\mathrm{A}$. adiantum-nigrum in the British Isles. Br. Fern Gaz., 12 (2): 103-107.

SLEEP, A. \& RYAN, P. - 1972 - The Guernsey Spleenwort - a new fern hybrid. Rep. Trans. Soc. Guernésiaise, 19 (2): 212-223.

SLEEP, A., ROBERTS, R.H., SOUTER, J.I. \& STIRLING, A. MCG. - 1978 - Further investigations on Asplenium cuneifolium in the British Isles. Br. Fern Gaz., 11 (6): 345-348.

VIDA, G. - 1963 - A new Asplenium (Sectio Ceterach) species and the problem of the origin of Phyllitis hybrida (Milde) C. Christ. Acta bot. hung., 9: 197-215.

VIDA, G. - 1966 - Az Evolucio Genetikai Alapjai. MTA Biol. Oszt. Közl., 9: $133-166$.

Comunicación presentada a la Reunión

Internacional de Pteridología (Algeciras, 1980)

Dirección del autor: Department of Plant Sciences, The University, Leeds, LS2 9JT, England. 


\begin{tabular}{|c|c|c|c|c|c|c|c|c|c|}
\hline $\begin{array}{l}\text { on } \\
\text { ô } \\
\text { \& }\end{array}$ & 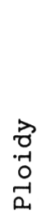 & 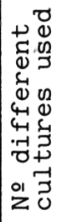 & 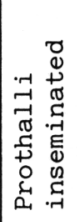 & 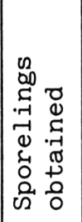 & $\begin{array}{l}\infty \\
\stackrel{\infty}{1} \\
0 \\
\infty\end{array}$ & $\begin{array}{c}0 \\
.1 \\
\cdots \\
0\end{array}$ & 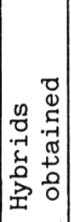 & 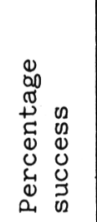 & $\begin{array}{l}\text { âj } \\
0 \\
-1 \\
0 \\
+1 \\
0\end{array}$ \\
\hline $\begin{array}{l}\text { P. fontanum } x \\
\text { A. foresiense }\end{array}$ & $3 x$ & 7 & 150 & 39 & 23 & 1 & 15 & $10 \%$ & $36^{\prime \prime}+36^{\prime}$ \\
\hline $\begin{array}{l}\text { P A. foresiense } \\
\times \text { A. fontanum }\end{array}$ & $3 x$ & 4 & 108 & 25 & 16 & 0 & 9 & $8.3 \%$ & $36^{\prime \prime}+36^{\prime}$ \\
\hline $\begin{array}{l}\text { A. obovatum } x \\
\text { A. foresiense }\end{array}$ & $3 x$ & 2 & 112 & 68 & 31 & 0 & 37 & $33 \%$ & $36^{\prime \prime}+36^{\prime}$ \\
\hline $\begin{array}{l}\text { P A. foresiense } \\
\times \text { A. obovatum }\end{array}$ & $3 x$ & 6 & 162 & 22 & 16 & 4 & 2 & $1.2 \%$ & $36^{\prime \prime}+36^{\prime}$ \\
\hline $\begin{array}{l}\text { A. onopteris } x \\
\text { A. foresiense }\end{array}$ & $3 x$ & 3 & 158 & 36 & 7 & 7 & 22 & $13.9 \%$ & $108^{\prime}$ \\
\hline $\begin{array}{l}\text { I. foresiense } \\
\times \text { A. onopteris }\end{array}$ & $3 x$ & 2 & 10 & 0 & 0 & 0 & 0 & - & - \\
\hline
\end{tabular}

Table II.- Synthetic hybrids involving A. foresiense $\star$.

Figure 2.- Crosses involving Asplenium foresiense $t$. Silhouettes of fertile fronds of species and hybrids, taken from two-year-old plants cultivated at Leeds. All reproduced at two-thirds natural size.

A. Synthesized triploid hybrid, AS/847, between A. onopteris (D) and A. foresiense (E).

B. Asplenium obovatum ( ) from Capo di Testa, Sardinia, Italy.

C. Synthesized triploid hybrid, AS/890, between A. obovatum $(B)$ and A. foresiense (E).

D. Asplenium onopteris ( $2 x$ ) from Aritzo, Sardinia, Italy.

E. Asplenium foresiense $(4 x)$ from Auvergne, France.

F. Synthesized triploid hybrid, AS/281, between A. fontanum (G) and A. foresiense (E).

G. Asplenium fontanum ( $2 x$ ) from Isère, France. 

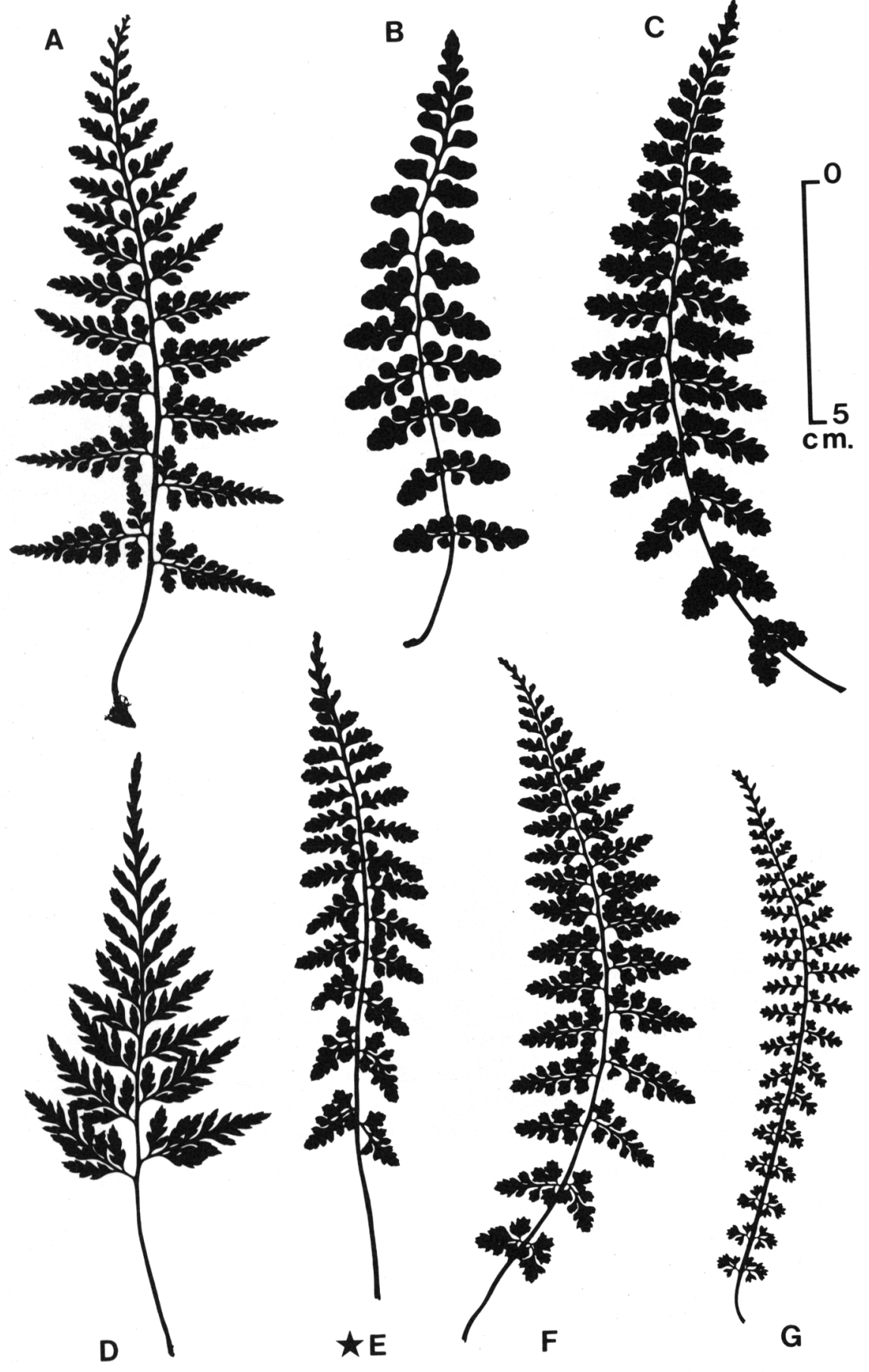


\begin{tabular}{|c|c|c|c|c|c|c|c|c|c|}
\hline $\begin{array}{l}\text { n } \\
\text { on } \\
0 \\
\text { c }\end{array}$ & $\begin{array}{l}\overrightarrow{0} \\
-1 \\
0 \\
-1 \\
2\end{array}$ & 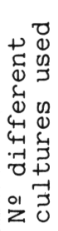 & 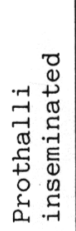 & 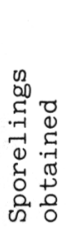 & $\begin{array}{l}\infty \\
4 \\
\infty \\
\infty\end{array}$ & 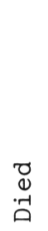 & 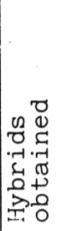 & 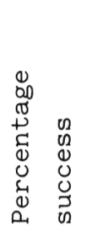 & $\begin{array}{l}\overrightarrow{0} \\
0 \\
0 \\
\circ \\
0 \\
+ \\
\overrightarrow{0}\end{array}$ \\
\hline $\begin{array}{l}\text { } 9 \text { A. majoricum } \\
\text { X A. fontanum }\end{array}$ & $3 x$ & 4 & 109 & 29 & 10 & 12 & $\underset{\sim}{7}$ & $6.4 \%$ & $36^{\prime \prime}+36^{\prime}$ \\
\hline $\begin{array}{l}\text { क A. onopteris } \mathrm{x} \\
\text { A. majoricum }\end{array}$ & $3 x$ & 2 & 26 & 9 & 7 & 0 & $\underset{\sim}{2}$ & $7.7 \%$ & $108^{\prime}$ \\
\hline $\begin{array}{l}\text { \& A. majoricum } \\
\times \text { A. onopteris }\end{array}$ & $3 x$ & 2 & 44 & 4 & 4 & 0 & 0 & - & - \\
\hline $\begin{array}{l}\text { A. viride } x \\
\text { A. majoricum }\end{array}$ & $3 x$ & 4 & 265 & 9 & 5 & 3 & $\frac{1}{\sim}$ & $0.38 \%$ & $108^{\prime}$ \\
\hline $\begin{array}{c}\text { ' A. majoricum } x \\
\text { A. foresiense }\end{array}$ & $4 x$ & 2 & 9 & 2 & 0 & 0 & $\underset{\sim}{2}$ & $22.2 \%$ & $36^{\prime \prime}+72^{\prime}$ \\
\hline
\end{tabular}

Table III.- Synthetic hybrids involving A. majoricum $\downarrow$.

Figure 3.- Crosses involving Asplenium majoricum $\downarrow$. Silhouettes of fertile fronds of species and hybrids, taken from two-year-old plants cultivated at Leeds. All reproduced at two-thirds natural size.

A. Asplenium foresiense (4x) from Auverge, France.

B. Synthesized tetraploid hybrid, AS/846, between A. majoricum (E) and A. foresiense (A).

C. Synthesized triploid hybrid, AS/256, between A. majoricum (E) and A. fontanum (D).

D. Asplenium fontanum (2x) from Isère, France.

E. Asplenium majoricum (4x) from Sóller, Majorca.

F. Asplenium viride (2x) from Hutton Roof, Westmorland, England.

G. Synthesized triploid hybrid, AS/961, between A. viride (F) and A. majoricum (E).

H. Asplenium onopteris (2x) from Aritzo, Sardinia, Italy.

I. Synthesized triploid hybrid, AS/830, between A. onopteris (H) and A. majoricum (E). 


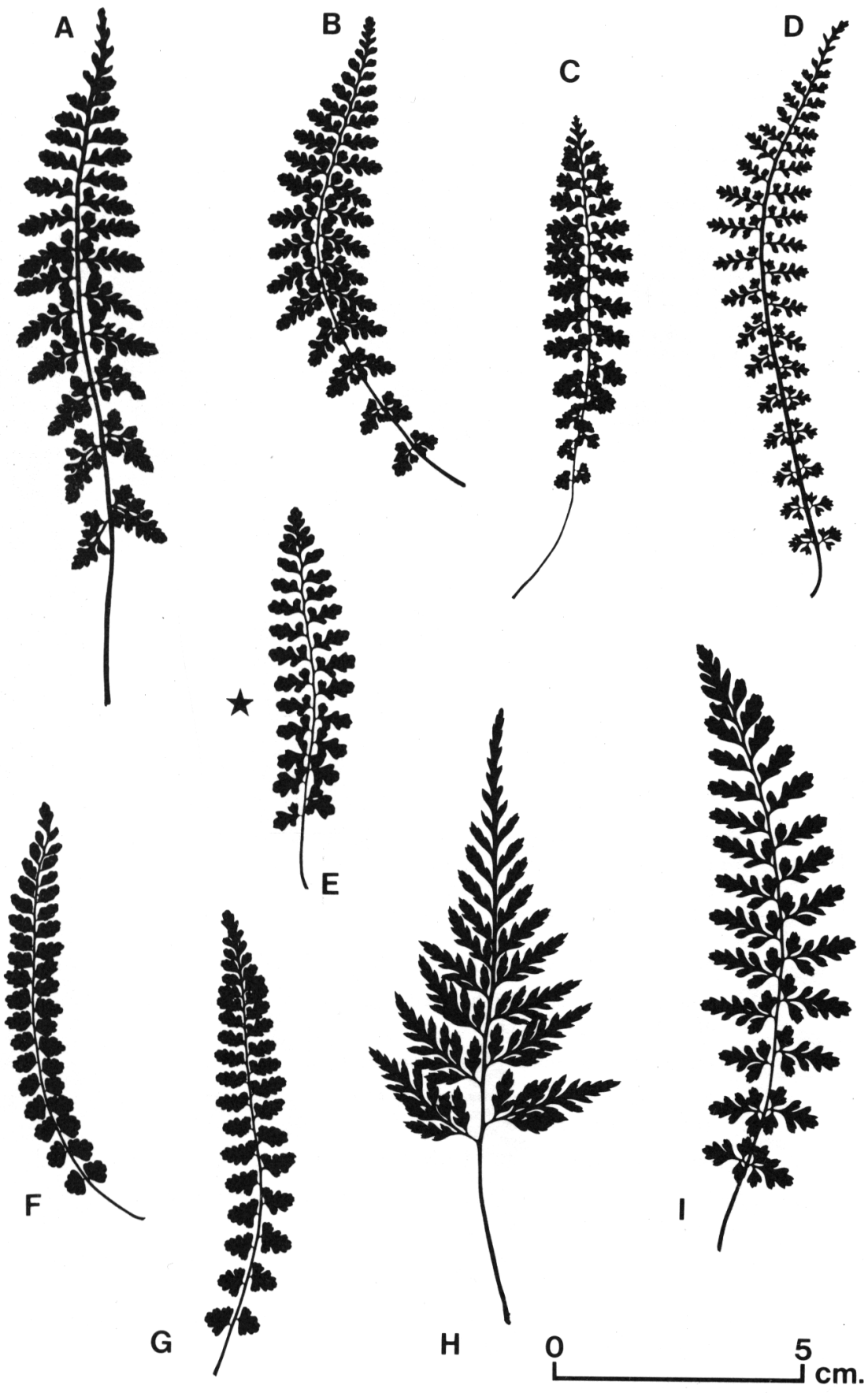




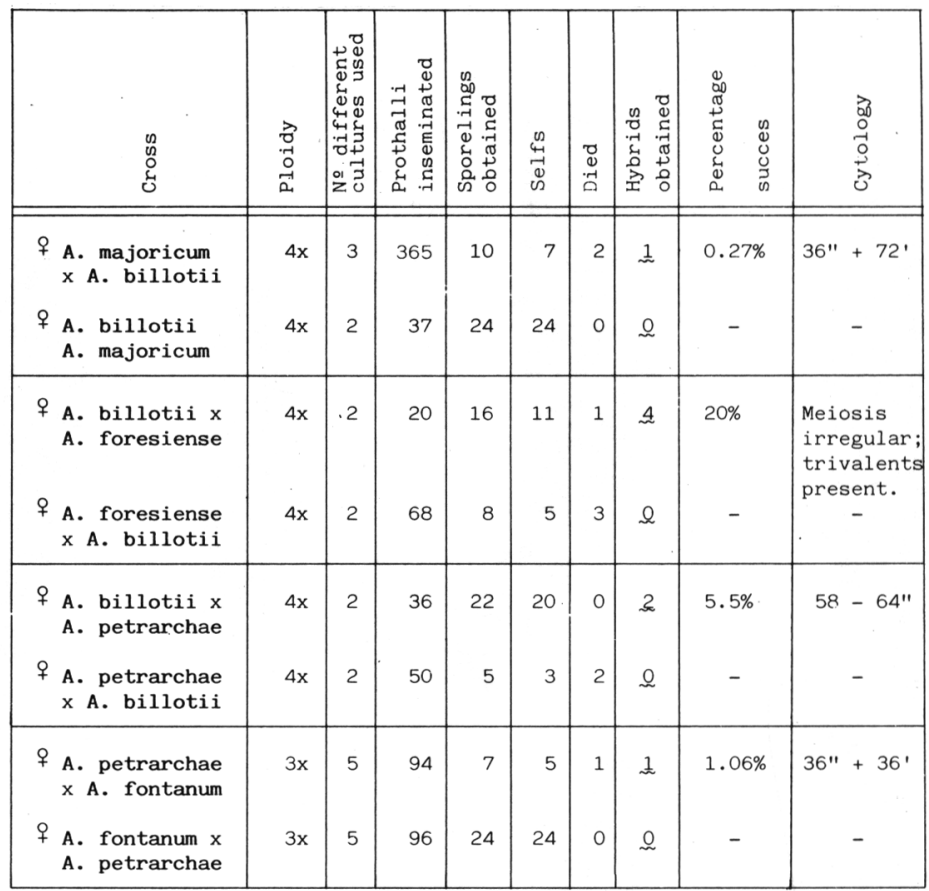

Table IV.- Synthetic hybrids involving Asplenium billotii and A. petrachae 潘.

Figure 4.- Crosses involving A. billotii $\downarrow$ and A. petrarchae:**. Silhouettes of fertile fronds of species and hybrids, taken from two-year-old plants cultivated at Leeds. All reproduced at two-thirds natural size.

A. Asplenium majoricum (4x) from Sólḷer, Majorca.

B. Synthesized tetraploid hybrid, AS/985, between A. majoricum (A) and A. billotii (E).

C. Asplenium foresiense (4x) from Auverge, France.

D. Synthesized tetraploid hybrid AS/1014, between A. billotii (E) and A. foresiense (C).

E. Asplenium billotii (4x) from Ronco,Ticino, Switzerland

F. Synthesized tetraploid hybrid, AS/977, between A. billotii (E) and A. petrarchae (G).

G. Asplenium petrarchae (4x) from Salon, Bouches-du-Rhône, France.

H. Synthesized triploid hybrid, AS/262, between A. petrarchae (G) and A. fontanum (I).

I. Asplenium fontanum (2x) from Isère, France. 


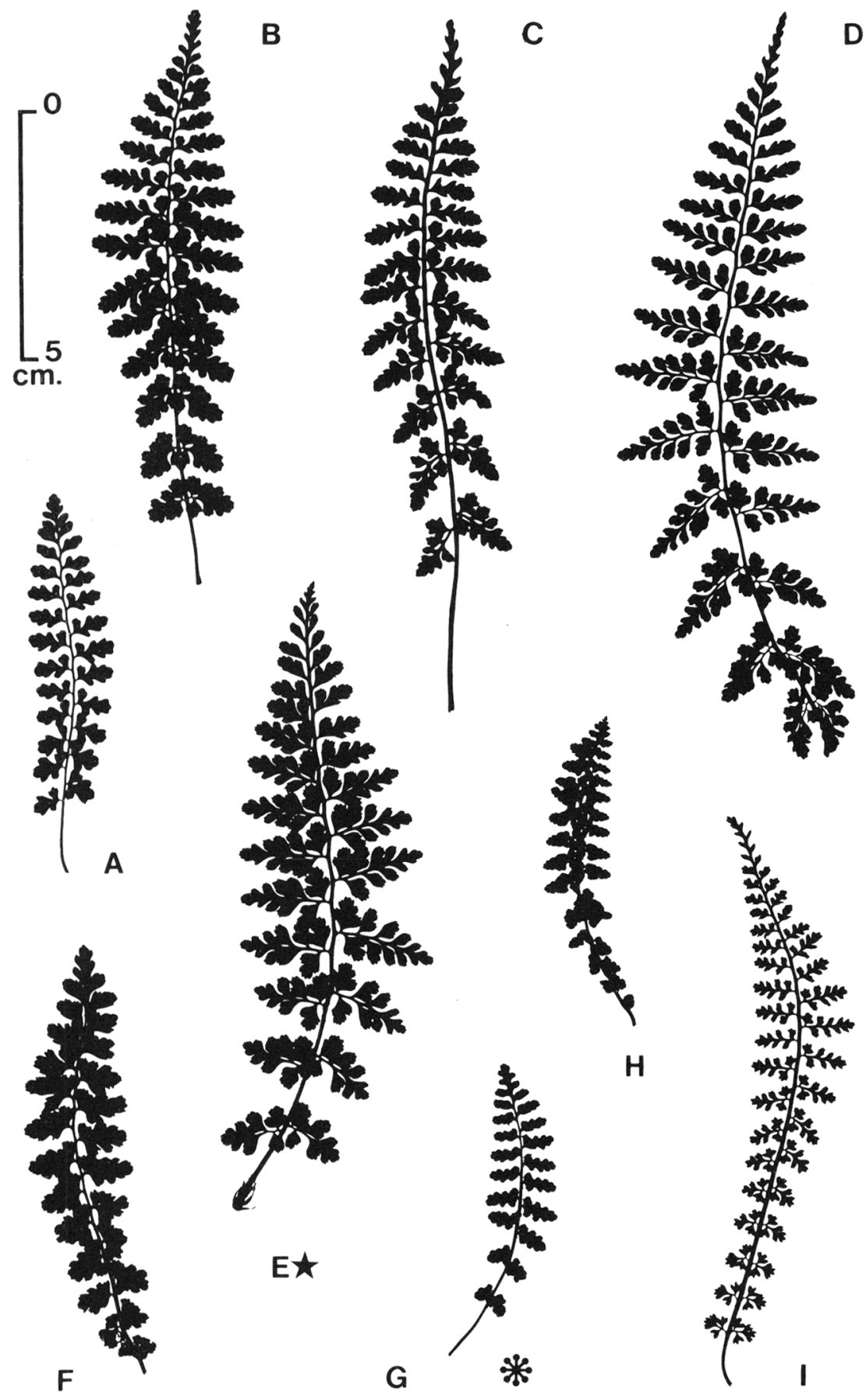


Plate I.- Cytology. Photomicrographs of permanent aceto-carmine squash preparations of spore mother cells at meiosis, all reproduced at a magnification of X 800 . Details of the method are given in Manton, 1950.

a. Synthesized triploid hybrid A. fontanum $x$ A. foresiense (AS/282ii). For explanatory diagram see Figure 5, A. Silhouette: Figure 2,F.

b. Synthesized triploid hybrid A. onopteris $x$ A. foresiense (AS/847i): For explanatory diagram see Figure 5,B. Silhouette: Figure 2, A.

c. Synthesized triploid hybrid A. obovatum $x$ A. foresiense (AS/900ii). For explanatory diagram see Figure 5,C. Silhouette: Figure 2,C.

d. Synthesized triploid hybrid A. petrarchae $x$ A. fontanum $(\mathrm{AS} / 262)$. For explanatory diagram see Figure 5,E. Silhouette: Figure 4, H.

e. Synthesized tetraploid hybrid A. majoricum $x$ A. billotii (AS/985). For explanatory diagram see Figure 5,G. Silhouette: Figure 4,B.

f. Synthesized tetraploid hybrid A. billotii x A. foresiense (AS/1014). Multivalent associations are present and for explanatory diagram see Figure 5,D . Silhouette: Figure 4, D.

g. Synthesized tetraploid hybrid between A. adiantum-nigrum from Guernsey and putative autotetraploid A. cuneifolium from Banff, Scotland. (AS/1088i). Cell in diakinesis, with 72 bivalent chromosomes clearly displayed. No diagram given.

h. Synthesized tetraploid hybrid A. billotii x A. petrarchae (AS/977). For explanatory diagram see Figure 5,F. Silhouette: Figure 4,F.

i. Synthesized tetraploid hybrid between putative autotetraploid A. cuneifolium from Lime Hill, Scotland and Phyllitis hybrida, Figure 7,B. (an allotetraploid having the origin P. sagittata $x$ Ceterach officinarum subsp. bivalens). (AS/ 1281i). Metaphase showing 142 unpaired chromosomes and 1 bivalent (arrowed). Note especially the large, barrel-shaped chromosomes of the Phyllitis genome. No diagram given.

j. Diakinesis in spore mother cell of "A. cuneifolium" from Glendaruel, Argyllshire, Scotland. (AMS/6/77). The plant is tetraploid, with 72 bivalent chromosomes clearly displayed. No diagram given.

k. Synthesized tetraploid hybrid between the Japanese A. kobayashii (Figure $7, A$ ) and putative autotetraploid A. cuneifolium from Banff, Scotland. (AS/1079ii). There is no significant pairing between any of the chromosomes, which appear as univalents. No diagram is given. Compare with photographs $i$ and 1 .

1. Synthesized tetraploid hybrid between A. kobayashii, Fig. 7, A, and A. adiantum-nigrum from Guernsey, Fig. 8, B. (AS) 1105iii). Metaphse showing 144 univalent chromosomes. No diagram given. 
Asplenium in the Iberian Peninsula
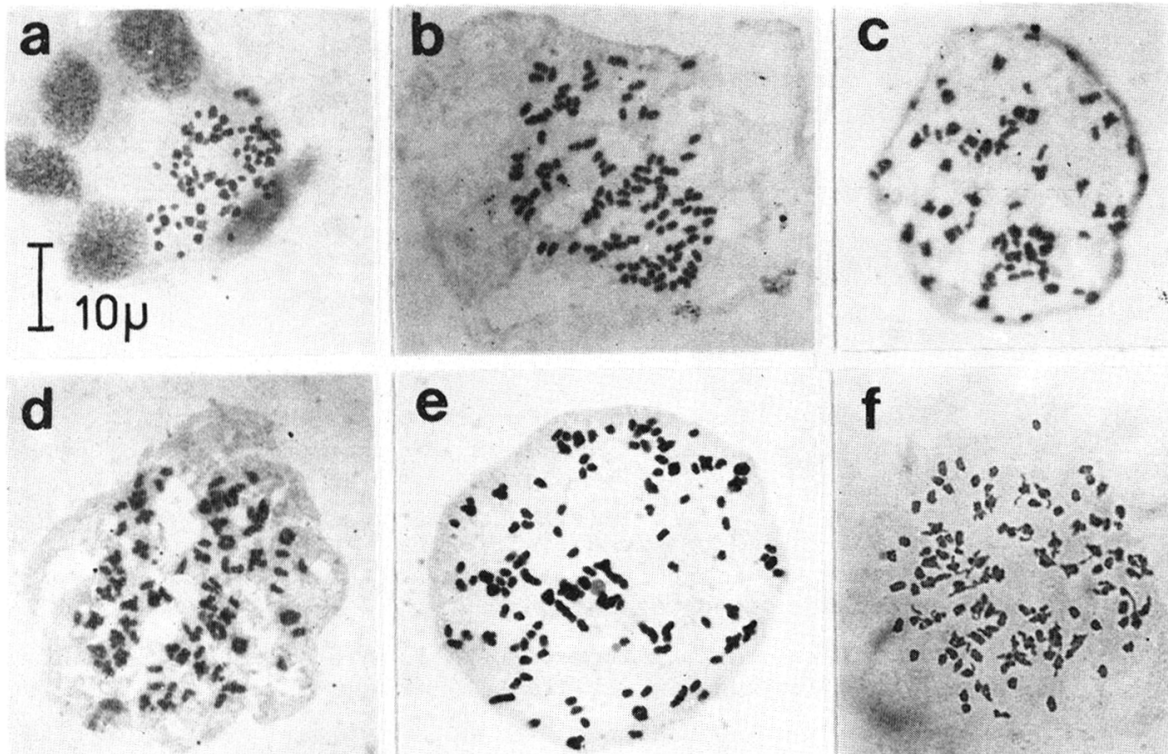

f
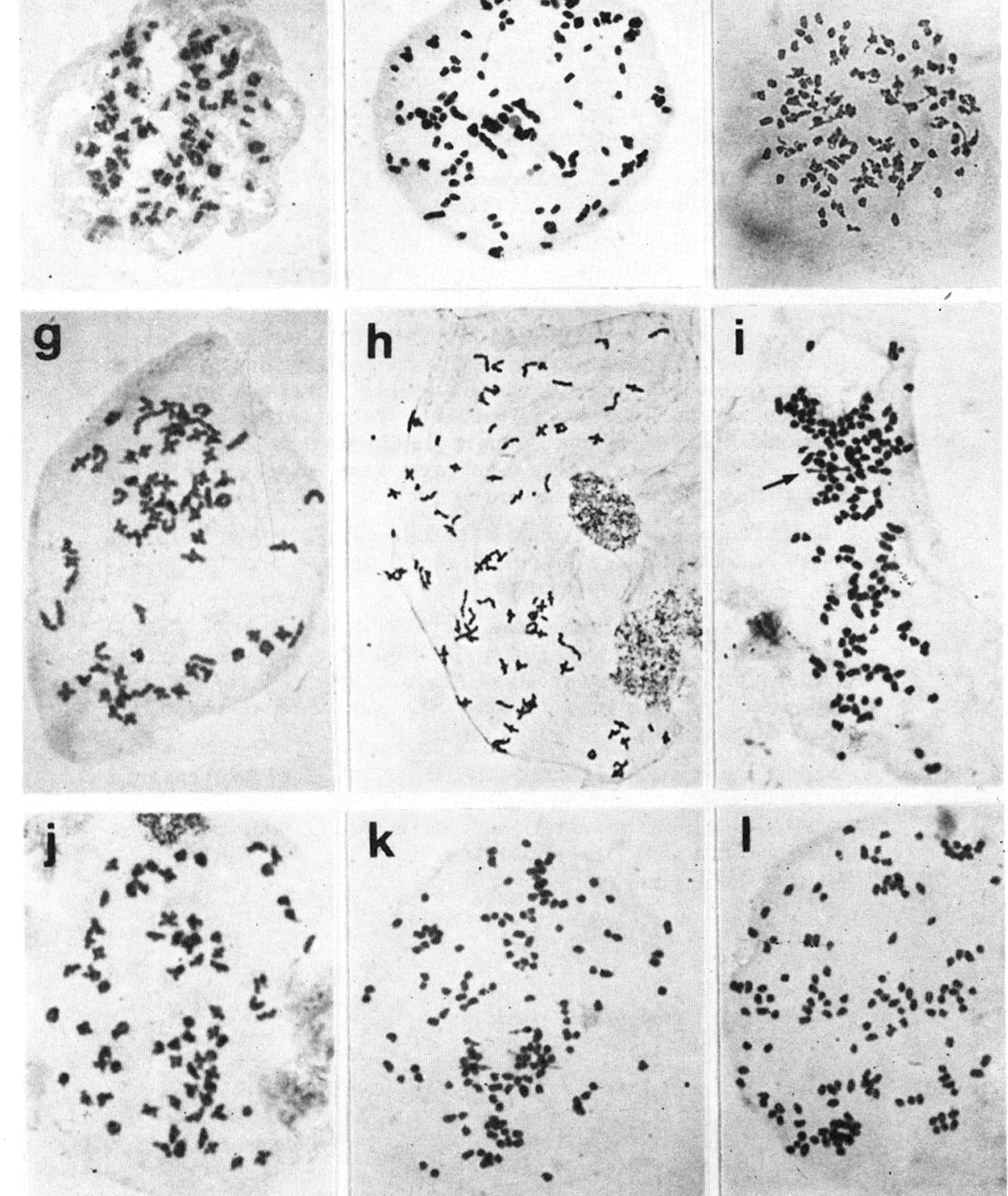
A. SLEEP

Figure 5. Cytology. Explanatory diagrams to selected photomicrographs in Plate $I$, all reproduced at a magnification of X 1200 .

A. A. fontanum $x$ A. foresiense, AS/282ii (Plate I,a). Triploid hybrid showing 36 bivalents (black) and 36 unpaired chromosomes (outlined) at metaphase.

B. A. onopteris $x$ A. foresiense, AS/847i (Plate I,b). Triploid hybrid showing 108 univalent chromosomes.

C. A. obovatum $x$ A. foresiense, AS/900ii (Plate I,c). Triploid hybrid. Diakinesis showing 36 bivalents (black) and 36 unpaired chromosomes (outlined).

D. A. billotii x A. foresiense, AS/1014 (Plate I,f). Tetraploid hybrid with 144 chromosomes. Suggested interpretation of chromosome pairing, with univalents outlined and bivalents and trivalents shown in black. Trivalent associations are indicated by arrows. Analysis from this cell: 15III +21 II $+57^{I}$. Other cells analysed gave similar results, the number of trivalents ranging from 12 to 15 per cell.

E. A. petrarchae $x$ A. fontanum, AS/262 (Plate I,d). Triploid hybrid at diakinesis; 36 bivalents (black) and 36 univalents (outlined) are present.

F. A. billotii $x$ A. petrarchae, AS/977 (Plate I,h). Tetraploid hybrid clearly showing 66 bivalent (black) and 12 univalent chromosomes at diakinesis. Other cells analysed showed similar pairing; in some the maximum pairing of 72 bivalents was seen.

G. A. majoricum x A. billotii, AS/985 (Plate I,e). Tetraploid hybrid clearly displaying 36 bivalents (black) and 72 univalent chromosomes at metaphase. Two bivalents are associated with the nucleolus. 
A

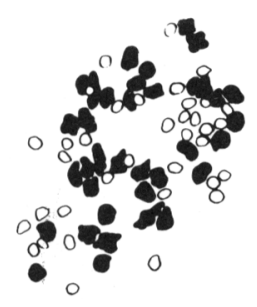

$$
\begin{aligned}
& \text { B } 8088_{0}: 0
\end{aligned}
$$

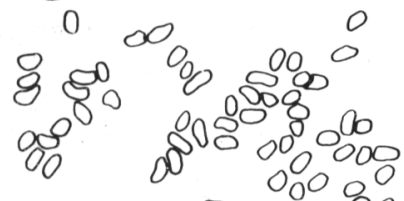

$$
\begin{aligned}
& \begin{array}{c}
0,0,08000080 \\
00.5090 \\
008800^{\circ}
\end{array}
\end{aligned}
$$

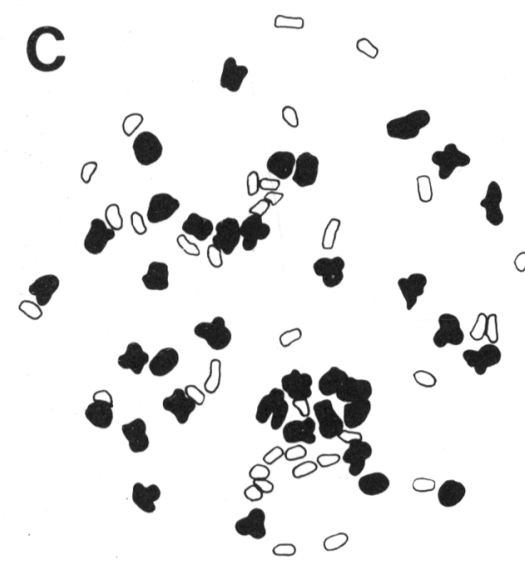

D

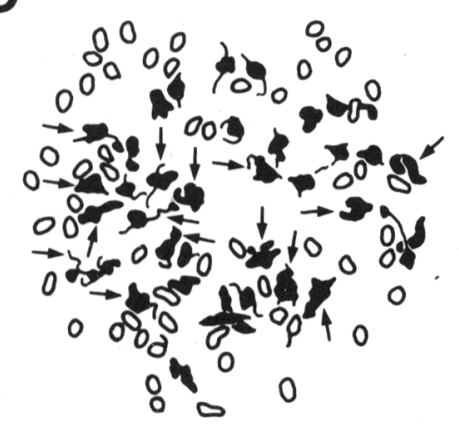

Asplenium in the Iberian Peninsula
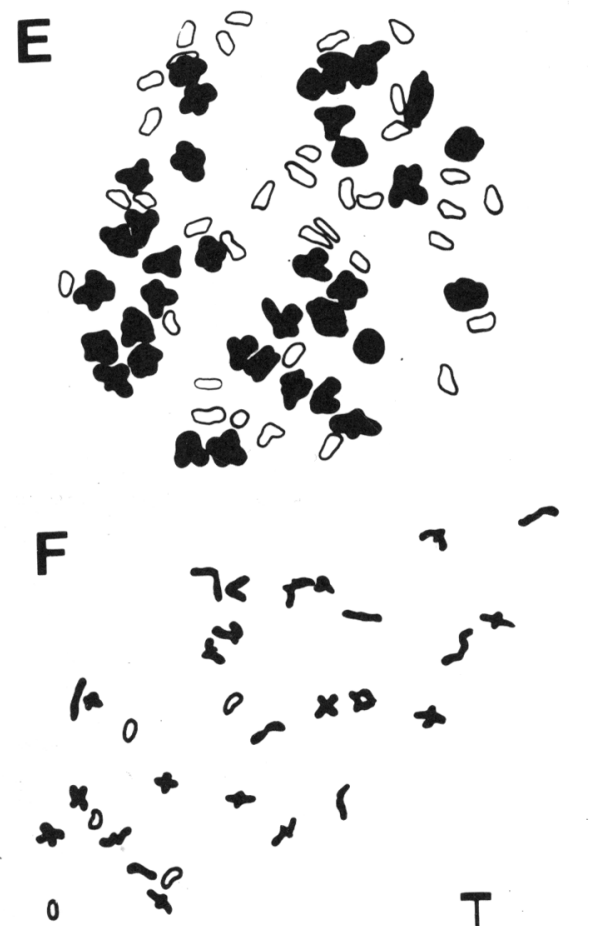

xp 1 y

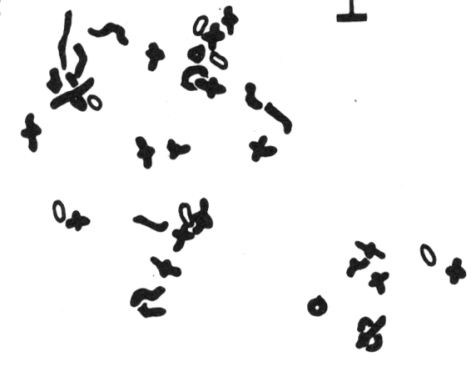


A. SLEEP

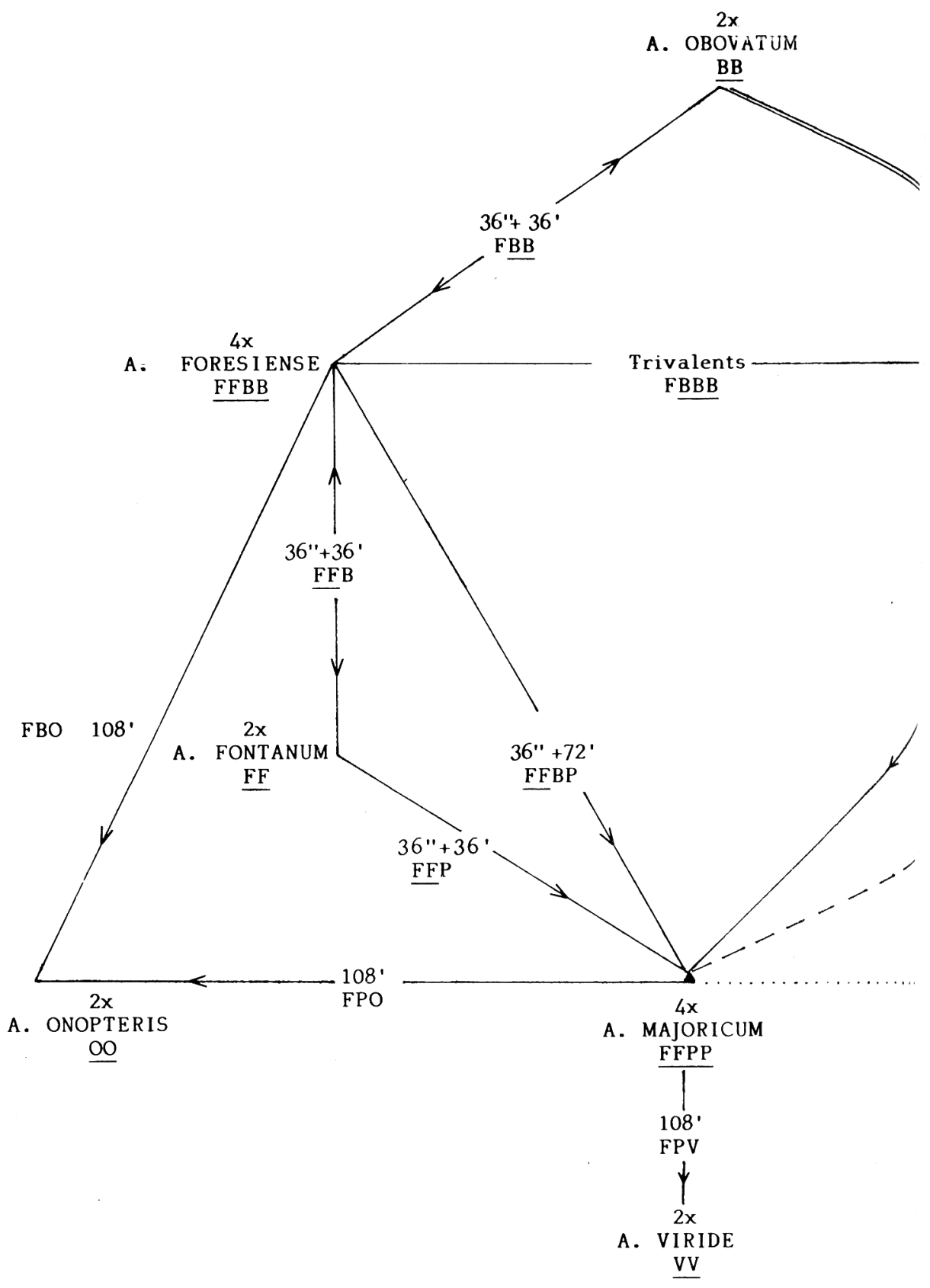




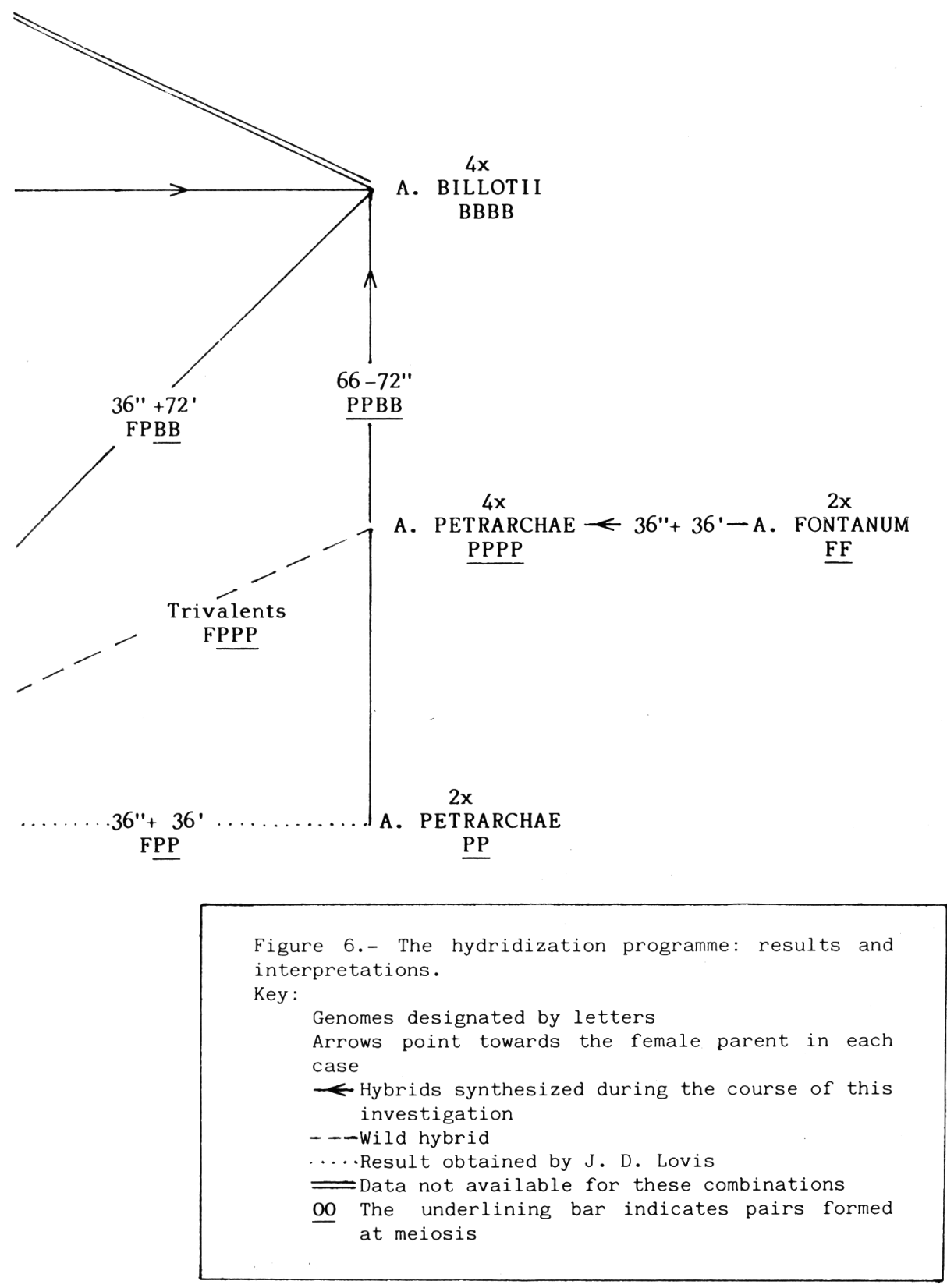




\begin{tabular}{|c|c|c|c|c|c|c|c|c|c|}
\hline $\begin{array}{l}n \\
\text { on } \\
\text { O } \\
\text { U }\end{array}$ & \begin{tabular}{|c|} 
\\
0 \\
0 \\
0 \\
0 \\
0.
\end{tabular} & 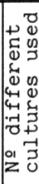 & 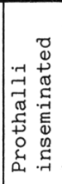 & 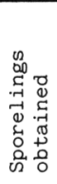 & $\begin{array}{l}\infty \\
\stackrel{\infty}{1} \\
\infty \\
\infty\end{array}$ & $\begin{array}{l}0 \\
0 \\
0 \\
-1 \\
0\end{array}$ & 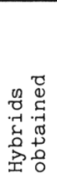 & $\begin{array}{ll}0 & \\
0 & \\
0 & \\
0 & 0 \\
5 & 0 \\
0 & 0 \\
0 & 0 \\
0 & 0 \\
0 & 0 \\
0 & 0\end{array}$ & $\begin{array}{l}\overrightarrow{3} \\
0 \\
0 \\
0 \\
+0 \\
+0 \\
0\end{array}$ \\
\hline $\begin{array}{l}\text { o "A. cuneifolium"x } \\
\text { P. hybrida }\end{array}$ & $4 x$ & 2 & 13 & 12 & 11 & 0 & $\underset{\sim}{1}$ & $7.7 \%$ & $1^{\prime \prime}+142 \prime$ \\
\hline $\begin{array}{l}\text { \&. hybrida } \\
\text { x" A. cuneifolium" }\end{array}$ & $4 x$ & 4 & 180 & 85 & 85 & 0 & 0 & - & - \\
\hline $\begin{array}{l}\text { "A. cuneifolium"x } \\
\text { A. kobayashii }\end{array}$ & $4 x$ & 3 & 76 & 53 & 49 & 4 & 0 & - & - \\
\hline $\begin{array}{l}\text { A. kobayashii x } \\
\text { "A. cuneifolium"* }\end{array}$ & $4 x$ & 4 & 121 & 131 & 4 & 6 & 121 & $100 \%$ & $\begin{array}{l}\text { All hybrids } \\
\text { analysed sho- } \\
\text { wed c. } 144^{\prime}\end{array}$ \\
\hline $\begin{array}{l}\text { A. adiantum-nigrum } \\
\times \text { A. kobayashii } \\
\text { \&. kobayashii } x \\
\text { A. adiantum-nigrum }\end{array}$ & $4 x$ & 2 & 121 & 89 & 41 & 2 & 46 & $\begin{array}{l}4.72 \% \\
38 \%\end{array}$ & $\begin{array}{l}\text { Hybrids of } \\
\text { both types } \\
\text { showed C. } 144^{\prime}\end{array}$ \\
\hline $\begin{array}{l}\text { A. adiantum-nigrum } \\
\mathrm{x} \text { "A. cuneifolium" } \\
\text { Scotland }\end{array}$ & $4 x$ & 3 & 104 & 104 & 0 & 10 & 94 & $90.38 \%$ & $\begin{array}{l}\text { All hybrids } \\
\text { analysed sho- } \\
\text { wed } 72 "\end{array}$ \\
\hline
\end{tabular}

Table V.- Crosses involving putative autotetraploid Asplenium cuneifolium from Scotland and Corsica. * Figures given include material from both Scotland and Corsica.

Figure 7.- The investigation of autopolyploidy in Asplenium cuneifolium. Silhouettes of species used in the investigation. All reproduced at two-thirds natural size.

A. Asplenium kobayashii, a rare Japanese allotetraploid having the origin Asplenium incisum $x$ Camptosorus sibiricus. AS/ 266a. Tomari-gawa, Hokkaido, Japan. Leg. A. Sleep, 27-71968. Frond from two year old plant in cultivation at Leeds.

B. Phyllitis hybrida, a rare allotetraploid species derived from a cross between Phyllitis sagittata and the diploid cytotype of Ceterach officinarum. Sown from spores from TR 917. Quanero islands, Yugoslavia. Frond from two year old plant in cultivation at Leeds.

C. Asplenium cuneifolum (2x). Wild collection from Bernstein, Austria. Leg. A. Sleep, J.D. Lovis \& T. Reichstein, September, 1964.

D. Asplenium adiantum-nigrum (collected as A. cuneifolium). Wild collection from serpentine rocks, Sierra Bermeja, Province of Malaga, Spain. Leg. A. McG. Stirling, 28.5.1975.

E. Asplenium adiantum-nigrum (collected as A. cuneifolium). $4 x$. Wild collection from serpentine rocks at Corrycharmaig, Glen Lochay, Perthshire, Scotland. Leg. A. McG. Stirling, 2.9.1973.

Compare Figure 7,D and $\mathrm{E}$ with Figure 8, B. 

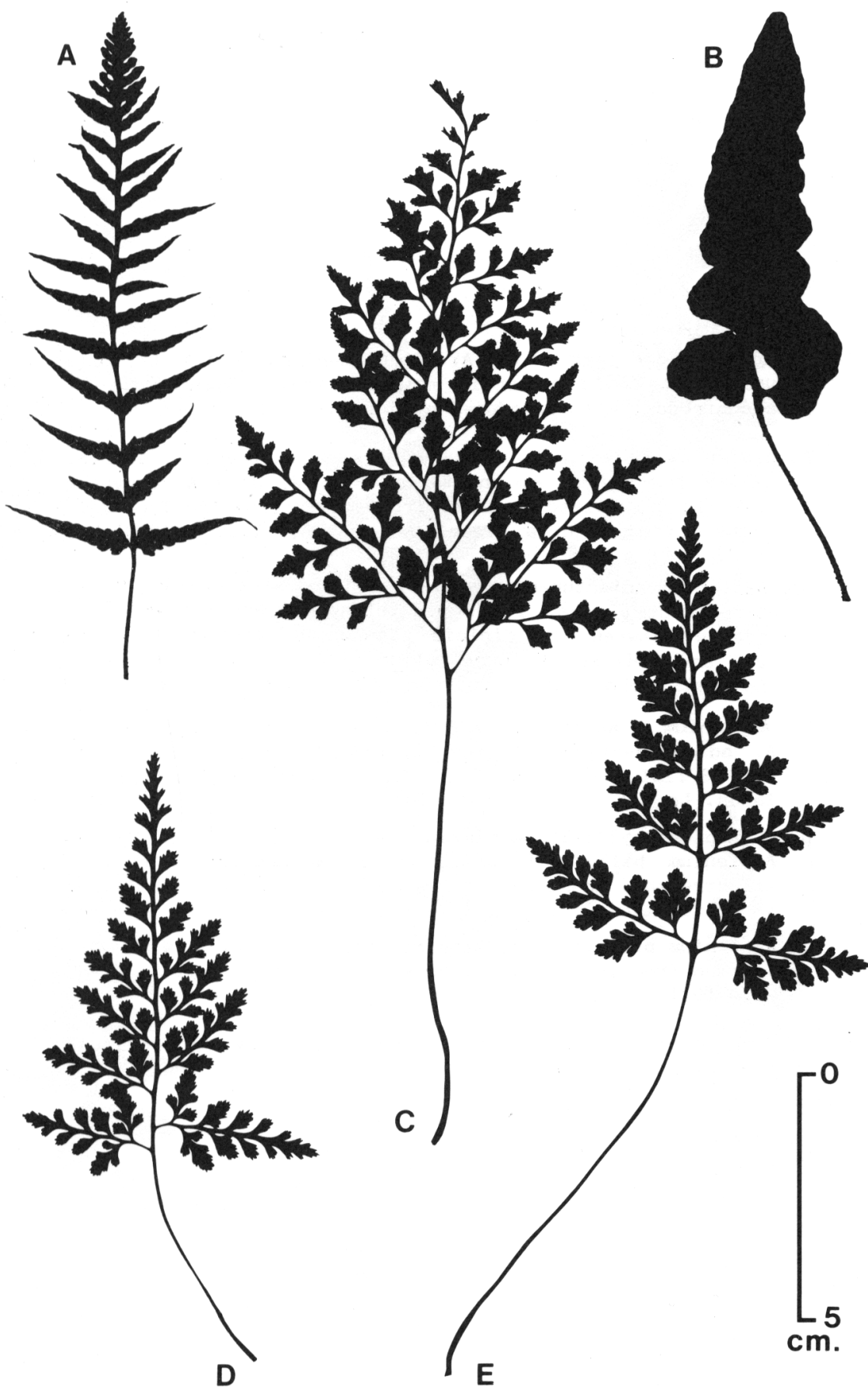
Figure 8.- Some taxa of the A. adiantum-nigrum and A. billotii groups which could occur in mainland spain. Silhouettes of pressed fronds, all reproduced at half natural size.

A. Asplenium balearicum. A very rare allotetraploid species having the origin A. onopteris (Fig. 2, D) $x$ A. obovatum (Fig. 2, B). Raised in Basel from spores from the Type collection from Majorca (locality unknown). Leg. E. O'Nions, 1952.

B. Asplenium adiantum-nigrum. A common and widespread species throughout Europe, it is allotetraploid and derived from across between the diploid species A. onopteris (Figs. 2, D and 3,H) and A. cuneifolium (Fig. 7,C). AS/1112 (i). Le Guet, Cobo, Câtel, Guernsey. Leg. A. Sleep, 19.4.1971.

C. Asplenium $x$ sarniense, the wild tetraploid hybrid between A. adiantum-nigrum (B) and A. billotii (E, also Fig. 4, E). AS/1101. Les Pres, St. Peter's, Guernsey, Channel Islands. Leg. A. Sleep, 23.4.1971.

D. $X$ Asplenophyllitis microdon, the triploid hybrid between Asplenium billotii (E) and Phyllitis scolopendrium (not illustrated). Frond from the synthesized hybrid, JDL 1821A, in cultivation at Leeds.

E. Asplenium billotii (see also Fig. 3, E). AS/1107. Wild collection from les Pres, St. Peter's, Guernsey. Leg. A. Sleep, 23.4.1971.

$B, C$ and $E$ all from plants collected in Guernsey and previous-

ly in cultivation at Leeds. 


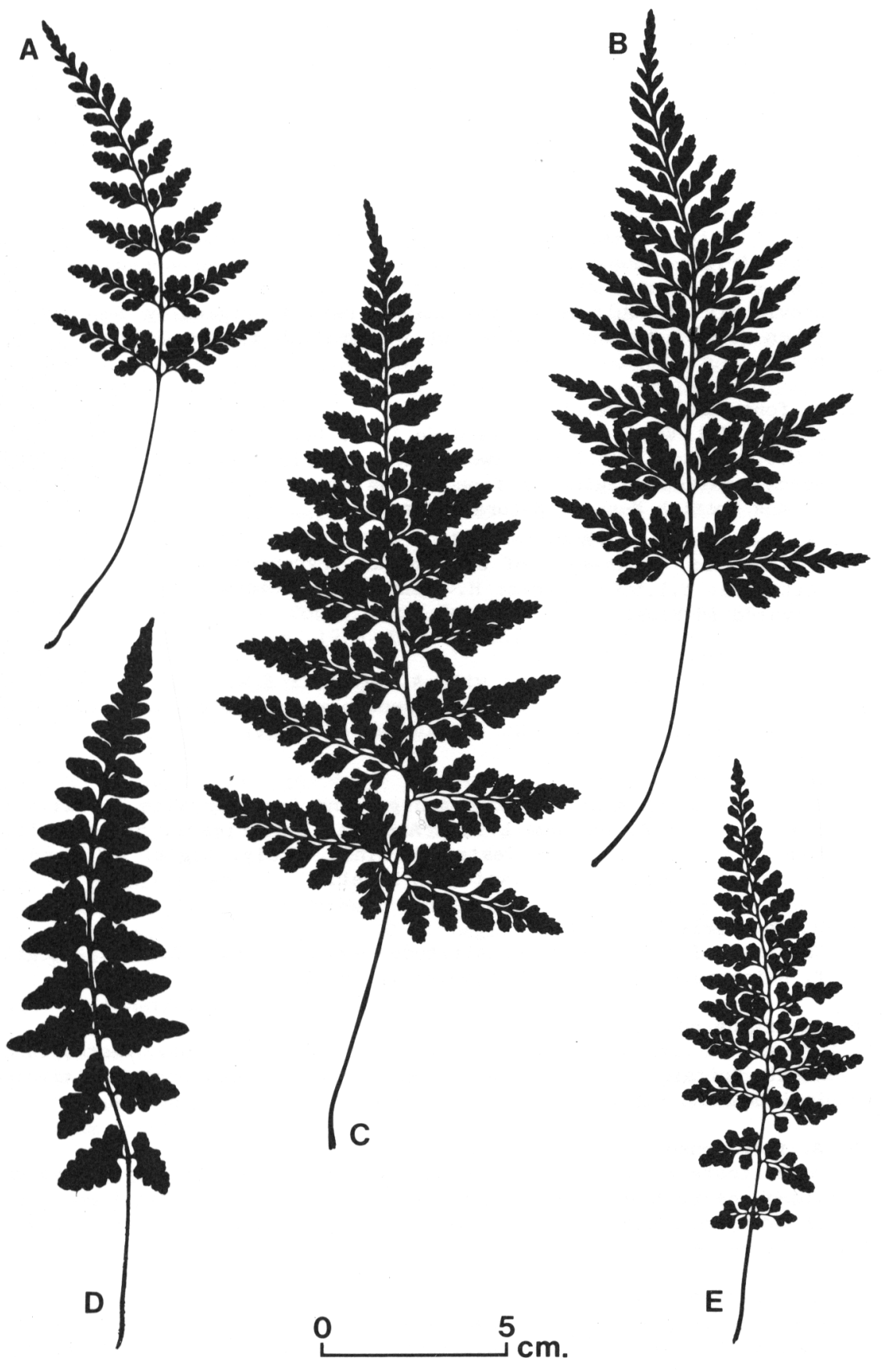


1. A. fontanum (L.) Bernh. AS/24; AS $/ 25$

From steep woodland by roadside near Roche, between Villneuve and Aigle, Canton Vaudois, Switzerland. Growing in crevices of shaded, calcareous rocks with Polypodium australe Fée. Aspect: west-facing. Altitude: c.400m. Legit: Anne Sleep, 28.7.61. Two plants previously in cultivation at Leeds.

2. A. fontanum (L.) Bernh.

Exsc. Walter-Callé. 3me. fasc. 1946. № 180. Pyrénées françaises, Dept. Ariège, France. Fissures de rocs calcaires au-dessus de l'entrée de la grotte de Niaux. Legit: $\mathrm{Cl}$. Leredde. 31.8.46. Two plants previously in cultivation at Leeds, raised originally from spores taken from a herbarium sheet at the British Museum (Natural History).

3. A. fontanum (L.) Bernh.

Pas au Col Vert, near Villard de Lans, Dept. Isère, France. Legit: A.H.G. Alston, 29.9.49. Two plants previously in cultivation at Leeds, raised originally from spores taken from a herbarium sheet at the British Museum (Natural History).

4. A. fontanum (L.) Bernh. TR 16.

Val di Llo, south-east of Saillagouse, Pyrenees-orientales. France. Altitude: c.1,500m. Legit: H. Kunz and T. Reichstein, 12.8.57. Cultivated in Basel.

5. A. obovatum Viv. TR 621 .

On silicate rocks, growing with A. billotii F.W. Schultz. Altitude: c.150m. Trinité near Bonifacio, south-west Corsica. Legit: H. Kunz and $\mathrm{T}$. Reichstein, 16.4.62. Cultivated in Basel.

6. A. obovatum Viv. TR 123.

On north-facing granite rocks and growing together with A. billotii F.W. Schultz; A. marinum L. and Arenaria balearica L. nearby. Altitude: c.50m. Capo di Testa, Sardinia, Italy. Legit: H.L. and T. Reichstein, 6.10.59. Cultivated in Basel.

7. A. onopteris L. TR 114 .

Crevices of silicate rock. Altitude: 900m. Aritzo, Sardinia. Legit: T. Reichstein, 26.9.59. Cultivated in Basel.

8. A. viride Hudson

Cracks in exposed limestone pavement. Hutton Roof, Westmorland, Great Britain. Legit: Anne Sleep, 29.6.63. Previously cultivated in Leeds and raised originally from a wild spore collection.

9. A. foresiense Le Grand TR 34. On silicate rocks, and in crevices of dry stone walls by vineyards, along the path Brissago - Incella. West side of Lake Maggiore, south of Locarno, Canton Ticino. Switzerland. Altitude: c.300m. Legit: T. Reichstein, 18.5.59.

10. A. foresiense Le Grand Crevices of granite rocks, Val Vizézy, west of Montbrison in Auvergne, Dept. Loire, France. Altitude: c.550m. Legit: T. Reichstein, 30.5.59. Cultivated in Basel. 
11. A. foresiense Le Grand Eastern slope of the Col de Maz de l'Air, between Villefort and les Vans, Cevennes. Border of Depts. Lozère and Ardèche, France. Legit: T. Reichstein. Cultivated in Basel.

12. A. majoricum Litardière Crevices on the north-facing side of dry limestone walls forming the terraces of olive groves. With A. trichomanes L, Ceterach officinarum DC., Polypodium australe Fée, Selaginella denticulata (L.) Link and Sedum dasyphyllum L. Altitude: c. $250 \mathrm{~m}$. C'as Patro Lau, Barranc. Beyond Biniaralx, ESE of the town of Sóller, Majorca. Legit: J. Orell Casasnovas, 1959. Originally represented by specimens in the herbarium and in the Botanic Garden of Liverpool University. Raised at Leeds from spores from the plant in cultivation at Liverpool.

13. A. petrarchae (Guérin) DC. subsp. petrarchae. TR 358.

Crevices of limestone rocks to the east of the road between Pélisanne and Aurons, near Salon, west of Aix-en-Provence, Bouches-du-Rhône France. Altitude: c. $150 \mathrm{~m}$. Legit: T. Reichstein. Cultivated in Basel.

14. A. billotii F. W. Schultz TR 276.

Crevices of dry silicate wall near Ronco, south of Ascona, Ticino, Switzerland. A. foresiense Le Grand grows nearby. Altitude: 300m. Legit: T. Reichstein, 9.9.61. Cultivated in Basel.

15. A. adiantum-nigrum L.

Hedgebank near Le Douit, St. Peter's, Guernsey, Channel Islands. Legit: Patience Ryan, 1975. Stock plant cultivated in Leeds.

16. A. adiantum-nigrum L. $3 / 75$.

Glen Urquhart, Easterness, Scotland. Legit: A. McG. Stirling, 1975. Stock plant cultivated in Leeds.

17. "A. cuneifolium". JIS/76/12; JIS/76/7; JIS/76/2.

Bridgend, upper Deveron valley, Banff, Scotland. On serpentine rocks. Legit: Janet I. Souter, 1976. Stock plants in cultivation at Leeds.

18. "A cuneifolium".

Lime Hill, Loch Ard Forest, Stirling, Scotland. On serpentine rocks at an altitude of $150-170 \mathrm{~m}$. Legit: A.McG. Stirling, 1975. Stock plant cultivated in Leeds.

19. "A. cuneifolium". TR 3839.

Between Sermano and Bustanico, Corsica, France. Growing on rocks of serpentine s.1. (green schists). Legit: R. Deschatres, 9.7.74. Originally raised in Basel from spores from the plant collected in Corsica. Stock plants were subsequently raised in Leeds from spores from Basel.

20. A. kobayashii Tagawa. AS/265; AS/266a; AS/267(i).

From limestone cliffs by side of Tomari River, Mt. Ohira, Hokkaido, Japan. Legit: Anne Sleep, 27.7.68. Stock plants in cultivation at Leeds.

21. Phyllitis sagittata (DC.) Guinea \& Heywood. TR 917. Quanero Islands, Croatia, Yugoslavia. Legit: T. Reichstein. Stock plants in cultivation at Leeds, originally raised from spores from Basel. 